Article

\title{
Synthesis, Crystal Structure, and Biological Evaluation of Fused Thiazolo[3,2-a]Pyrimidines as New Acetylcholinesterase Inhibitors
}

\author{
Mohamed Y. Mahgoub ${ }^{1,2}\left(\right.$, Awatef M. Elmaghraby ${ }^{1, *}$,, Abd-Elfttah A. Harb ${ }^{1}$, \\ João L. Ferreira da Silva ${ }^{2}$ (D) , Gonçalo C. Justino ${ }^{2}$ and M. Matilde Marques ${ }^{2}$ (D) \\ 1 Chemistry Department, Faculty of Science, South Valley University, Qena 83523, Egypt; \\ m.mahgoub2013@gmail.com (M.Y.M.); alifaragharb@gmail.com (A.-E.A.H.) \\ 2 Centro de Química Estrutural, Instituto Superior Técnico, Universidade de Lisboa, 1049-001 Lisboa, Portugal; \\ joao.luis@tecnico.ulisboa.pt (J.L.F.d.S.); goncalo.justino@tecnico.ulisboa.pt (G.C.J.); \\ matilde.marques@tecnico.ulisboa.pt (M.M.M.) \\ * Correspondence: awatef_elmaghraby@yahoo.com \\ Academic Editors: David Díez and María Ángeles Castro \\ Received: 26 May 2019; Accepted: 19 June 2019; Published: 21 June 2019

\begin{abstract}
A new series of thiazolo[3,2-a]pyrimidine bromide salt derivatives $7 \mathbf{a}-\mathbf{d}$ were synthesized from 3,4-dihydropyrimidinethione precursors. The target compounds were fully characterized by $1 \mathrm{D}$ - and 2D-NMR, high resolution ESI-MS/MS and single crystal X-ray diffraction analysis, which confirmed a regioselective $5 \mathrm{H}$ cyclization of the dihydropyrimidinethiones. All target compounds were evaluated in vitro as human acetylcholinesterase ( $h \mathrm{AChE}$ ) inhibitors via an Ellman-based colorimetric assay and showed good inhibition activities (better than $70 \%$ at $10 \mu \mathrm{M}$ and $\mathrm{IC}_{50}$ values in the $1 \mu \mathrm{M}$ range). Molecular docking simulations for all target products into $h \mathrm{AChE}$ were performed and confirmed strong binding to the enzyme. These results provide a promising and new starting point to improve acetylcholinesterase inhibitors and explore novel treatment options against Alzheimer's disease.
\end{abstract}

Keywords: thiazolopyrimidines; acetylcholinesterase inhibition; molecular docking; crystal structures

\section{Introduction}

Alzheimer's disease (AD) is a chronic and progressive neurodegenerative disorder that is the leading cause of dementia in elderly people, accounting for $60-80 \%$ of all cases. According to the World Health Organization (WHO), AD affected about 50 million people worldwide in 2018 [1]. AD destroys brain cells and nerves, disrupting the neurotransmitters that carry messages in the brain, especially those responsible for storing memories. Acetylcholinesterase (AChE) is the enzyme that catalyzes the hydrolysis of the neurotransmitter acetylcholine (ACh) into acetic acid and choline (Scheme 1). According to the cholinergic hypothesis, depleted levels of ACh are associated with AD [2,3].

As a result, AChE inhibitors, such as tacrine, donepezil, galantamine, and rivastigmine (Figure 1), represent the major class of drugs approved and prescribed for AD. These drugs promote memory function and delay the cognitive decline, although they do not change the underlying pathology [4].

Thiazolopyrimidine derivatives have been the focus of intense research in recent years. Among the various members of this class, thiazolo[3,2-a]pyrimidines are particularly interesting. They have been reported to inhibit specific enzymes, such as AChE [5], cell division cycle (Cdc) 25B phosphatase [6], casein kinase 2 [7], YycG histidine kinase [8], 2-methylerythritol 2,4-cyclodiphosphate synthase (IspF) proteins from Mycobacterium tuberculosis, Plasmodium falciparum, and Arabidopsis thaliana [9], and xanthine oxidase [10]. While the precise biological targets remain to be elucidated in some cases, 
thiazolo[3,2-a]pyrimidines have widely been reported to possess anti-cancer [11], anti-inflammatory and analgesic [12-15], anti-microbial, antibiofilm, antioxidant, DNA cleavage [8,16-20], antiviral [21,22], anti-Parkinsonian [23], antidiabetic [24], antihypertensive, and inotropic [25] activities. Other possible applications include their use as antimalarials and inhibitors of HIV reverse transcriptase $[9,26]$, as well as antagonists of the 5-HT2 serotonin receptor, with potential interest for the treatment of depression $[27,28]$. Other non-therapeutic uses for thiazolo[3,2-a]pyrimidines include inhibition of mild steel corrosion [29], and dimeric thiazolo[3,2-a]pyrimidinones have been proposed for the development of pigments, sensitizers in solar cells, and molecular switches [30]. As part of a program aiming to obtain new potent AD modifying agents, we report herein a new small series of AChE inhibitors based on a fused thiazolopyrimidine core. The plausible binding interactions of two representative compounds at the active site of human AChE are also discussed.<smiles>CC(=O)OCC[N+](C)(C)C</smiles>

Acetylcholine (ACh)

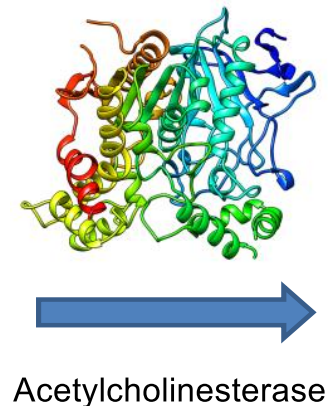

(AChE)<smiles>CC(=O)O[N+](C)(C)CCO</smiles>

Scheme 1. The hydrolysis of acetylcholine (ACh) by acetylcholinesterase (AChE) into acetic acid and choline.<smiles>COc1cc2c(cc1OC)C(=O)C(CC(C)CCI)C2</smiles>

Tacrine<smiles>CCN(C)C(=O)Oc1cccc(C(C)N(C)C)c1</smiles>

Rivastigmine<smiles>COc1ccc2c3c1O[C@H]1C[C@H](O)C=CC31CCN(C)C2</smiles>

Galantamine

Figure 1. Structures of approved AChE inhibitors.

\section{Results and Discussion}

\subsection{Synthesis}

Herein, a new series of thiazolo[3,2-a]pyrimidines $\mathbf{7 a - d}$, were designed and synthesized. Initially, 3,4-dihydropyrimidinethiones (DHPMs) $4 \mathbf{a}, \mathbf{b}$ were prepared by a multicomponent Biginelli-type reaction based on condensation of aldehydes $\mathbf{1}$, ethyl benzoylacetate 2 and thiourea 3 , as previously described [31] (Scheme 2). Then, a series of fused thiazolo[3,2-a]pyrimidines $7 \mathbf{a}-\mathbf{d}$ were synthesized in good yields, in a regioselective manner, through the intermediate 6 by cyclization of DHPMs $4 \mathbf{a}, \mathbf{b}$ 
with phenacyl bromides 5 under refluxing conditions in ethanol for 12-15 h (Scheme 3). The bromide salts were used for biological activity measurements. For comparative characterization purposes, compound $7 \mathrm{~b}$ was also neutralized to the corresponding product 9 .

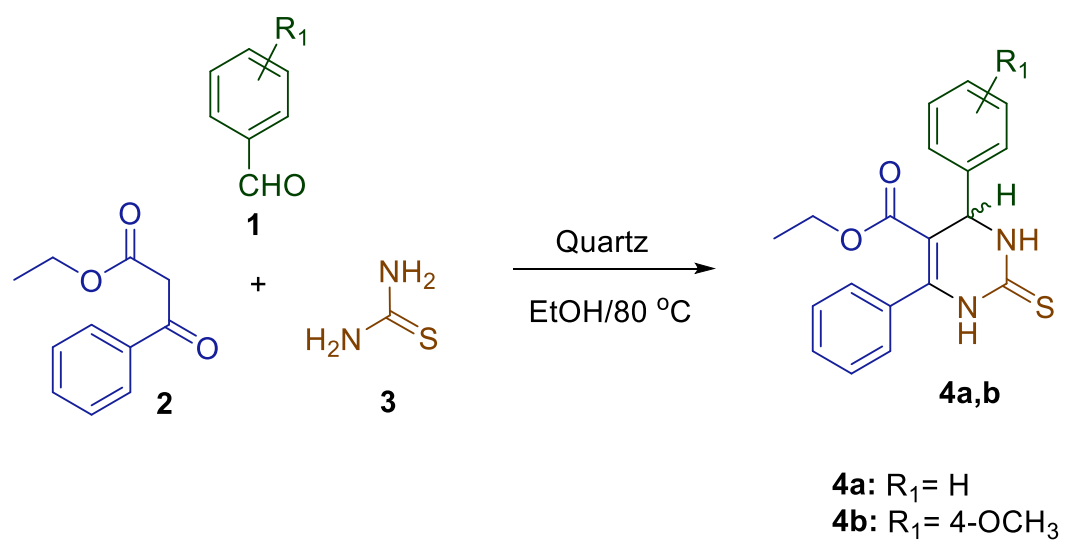

Scheme 2. Synthesis of 3,4-dihydropyrimidinethiones (DHPMs) $4 \mathbf{a}, \mathbf{b}$ by a multicomponent Biginelli-type reaction.<smiles>[R]c1ccc(C2NC(=S)NC(c3ccccc3)=C2C(=O)OCC)cc1</smiles><smiles>COc1ccc(C(=O)CBr)cc1</smiles><smiles>[R]c1ccc(C2=CSC3=NC(c4ccc([R])cc4)C(c4ccccc4)=C(C(=O)OCC)N23)cc1</smiles><smiles>[R]c1ccc(C2=CSC3=NC(c4ccc([R])cc4)C(c4ccccc4)=C(C(=O)OCC)N23)cc1</smiles>

8a-d $7 H$-form<smiles>[R1]c1ccc(C2C(C(=O)OCCCC)C(c3ccccc3)NC(O)N2SCC(=O)c2ccccc2)cc1</smiles>

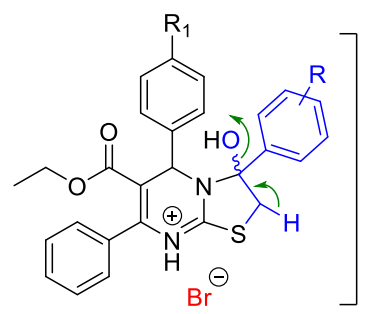

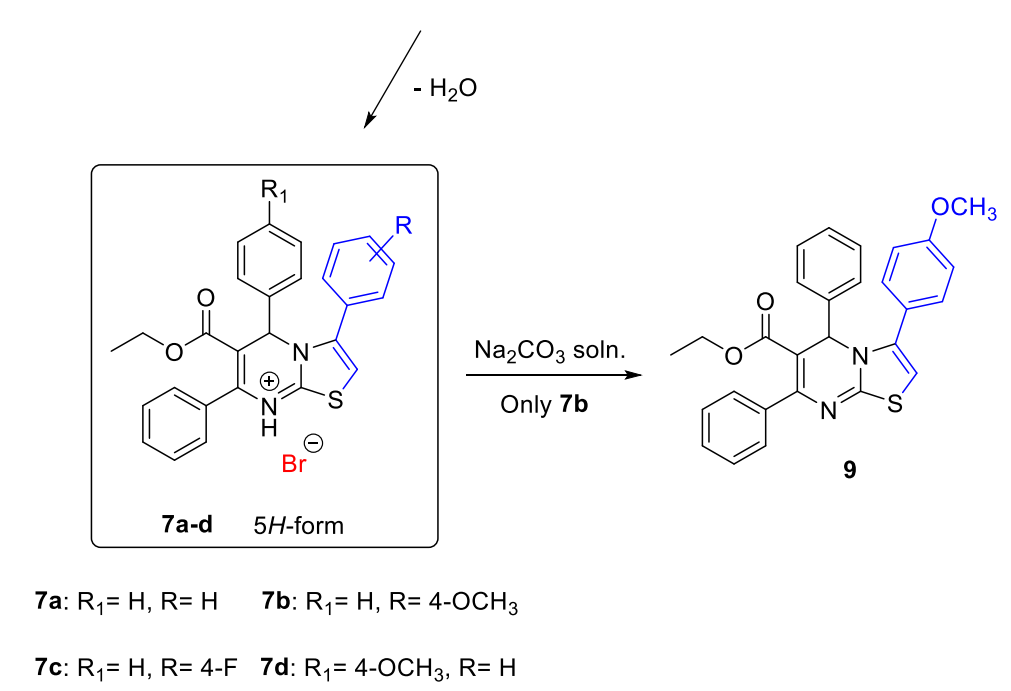

Scheme 3. Synthesis of fused thiazolo[3,2-a]pyrimidines $\mathbf{7 a - d}$ and $\mathbf{9}$.

\subsection{Structural Characterization}

The DHPMs $\mathbf{4 a}$, $\mathbf{b}$ and the thiazolo[3,2-a]pyrimidine salts $\mathbf{7 a - d}$ were fully characterized by 1Dand 2D-NMR, high resolution mass spectrometry (HRMS), and single crystal X-ray diffraction analysis.

\subsubsection{NMR Data}

The NMR spectra were fully consistent with the expected structures. The most characteristic features in the NMR spectra of DHPMs $\mathbf{4 a}, \mathbf{b}$ were the methine proton and carbon shifts, observed at $\delta$ 
5.27 and 54.08 ppm, respectively, in $\mathbf{4 a}$ and at $\delta 5.22$ and $53.52 \mathrm{ppm}$, respectively, in $\mathbf{4 b}$. Additionally, the two exchangeable NHs were observed at downfield shifts around $\delta 9.7 \mathrm{ppm}$ for N3-H and $\delta 10.4$ ppm for N1-H. Using a HMBC pulse sequence, 2- and 3-bond correlations were observed between the methine proton and nearby carbons $(C=S, C=O, C 5$, and $C 6)$, thus confirming the structural characterization.

Theoretically, the intramolecular cyclization of DHPMs with phenacyl bromide derivatives might afford two possible isomeric products: $5 H$-thiazolo[3,2-a]pyrimidines $7 \mathbf{a}-\mathbf{d}$ and 7H-thiazolo[3,2-a]pyrimidines 8a-d. However, a single product was obtained in all instances, presumably due to the higher conjugation (and thereby increased contribution) of the tautomer shown in Scheme 3 for the non-fused precursor 6, compared to the other possible tautomeric form (not shown). Cyclization was confirmed by the absence of thioamide NH resonances in the NMR spectra of $\mathbf{7 a}-\mathbf{d}$, along with the presence of an aromatic proton singlet $(\mathrm{C} 2-\mathrm{H})$ at around $\delta 7.15-7.30 \mathrm{ppm}$ and the corresponding C2 resonance at $\delta 113.00-114.60$ ppm. Moreover, compared with $4 \mathbf{a}, \mathbf{b}$, the further downfield shifts observed for the methine proton and carbon resonances upon cyclization (Table 1) were consistent with formation of the $5 \mathrm{H}$ isomers $\mathbf{7 a}-\mathbf{d}$. This was further corroborated by single crystal X-ray diffraction characterization ( $c f$. paragraph below). Neutralization of $\mathbf{7 b}$ yielded compound $\mathbf{9}$, which had characteristic proton (C2-H) and carbon (C2) resonances at $\delta 6.20$ and 103.04 ppm, respectively, slightly upfield from those of $\mathbf{7 b}$, as expected ( $c f$. experimental section and Supplementary data).

Table 1. ${ }^{1} \mathrm{H}$ - and ${ }^{13} \mathrm{C}$-NMR chemical shifts $(\delta$, in ppm) for the methine proton $(\mathrm{C} 5-\mathrm{H})$ and carbon $(\mathrm{C} 5)$ for all compounds discussed in the paper.

\begin{tabular}{cccccccc}
\hline Comp. & $\mathbf{4 a}$ & $\mathbf{4 b}$ & $\mathbf{7 a}$ & $\mathbf{7 b}$ & $\mathbf{7 c}$ & $\mathbf{7 d}$ & $\mathbf{9}$ \\
\hline${ }^{1} \mathrm{H}-\mathrm{NMR}$ & 5.27 & 5.22 & 6.44 & 6.41 & 6.36 & 6.73 & 6.27 \\
\hline${ }^{13} \mathrm{C}-\mathrm{NMR}$ & 54.08 & 53.52 & 59.87 & 59.63 & 59.93 & 59.41 & 58.36 \\
\hline
\end{tabular}

For comparative purposes, the relevant carbon chemical shifts of compounds $\mathbf{7 b}$ and $\mathbf{9}$ are listed in Table 2. The most notable changes were observed for $\mathrm{C} 2, \mathrm{C7}$, and $\mathrm{C} 9$, which is consistent with protonation of N8 in compound $\mathbf{7 b}$. This assumption was further confirmed by single crystal X-ray diffraction characterization ( $c f$. Figure 2).

Table 2. Comparison of the relevant carbon chemical shifts ( $\delta$, in ppm) for the protonated compound $7 \mathrm{~b}$ and the non-protonated compound 9.

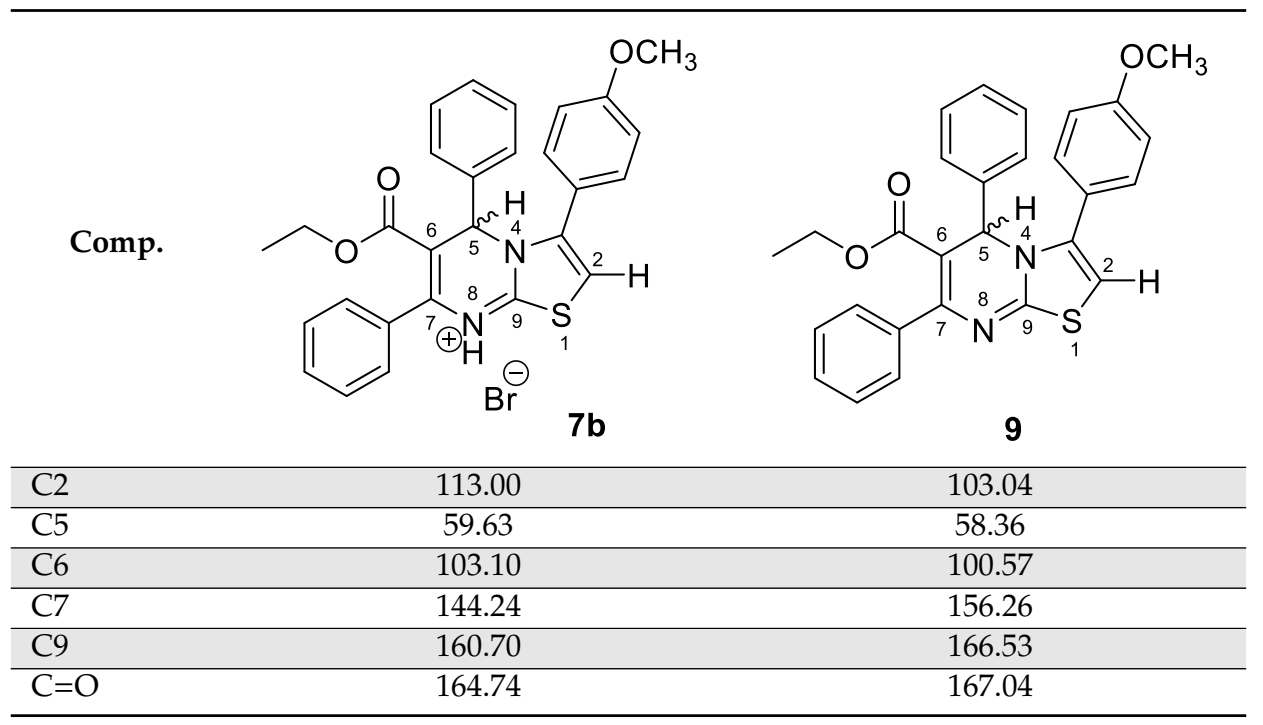



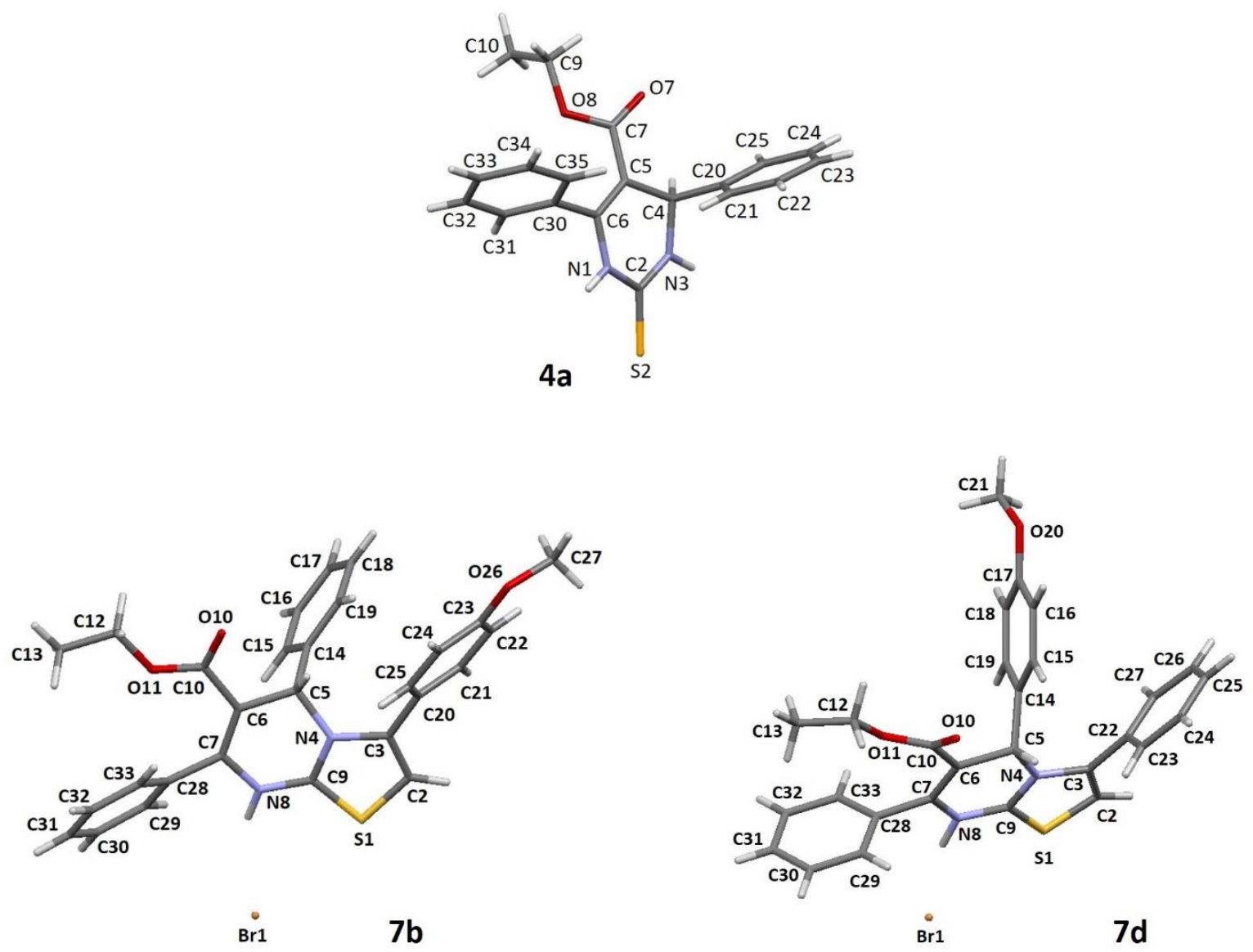

Figure 2. Diagrams of the molecular structures of compounds $4 \mathbf{a}, \mathbf{7 b}$, and $\mathbf{7 d}$ showing the atomic labelling scheme.

\subsubsection{X-Ray Diffraction Studies}

Single crystal X-ray diffraction analyses allowed us to confirm the structures of compounds 4 a, $\mathbf{7 b}, \mathbf{7 d}$ without ambiguity (Figure 2). Some of the relevant crystal parameters are reported in Table S1, in the Supplementary data section, while selected geometrical parameters are presented in Tables 3 and 4. Structurally-comparable bond lengths and angles were similar in all molecules and well within the expected range, as judged from extensive analysis of the values included in the CSD [32,33] (see also Tables S2 and S3, in the Supplementary data section, for full geometric parameters). All compounds had phenyl groups bonded to a quasi-planar dihydropyrimidine-containing central ring (Figure 2 and Tables 3 and 4) displaying very similar angles between the planes. Another fragment present in all compounds $(4 \mathbf{a}, 7 \mathbf{b}$, and $7 \mathbf{d})$ was the ester group, with torsion angle values $11.5^{\circ}, 21.9^{\circ}$, and $32.7^{\circ}$, respectively (Tables 3 and 4). Despite these slight differences, they all presented similar packing index values; in the absence of any stereochemical constraint it is possible to attribute the main geometrical features in these compounds to an attempt of achieving the most compact structures possible [34].

Concerning compound $4 a$ it was clear that $\mathrm{S}(2)-\mathrm{C}(2)$ has all the characteristics of a double bond: angles around $C(2)$ in the $116.4-121.9^{\circ}$ range and a bond length of $1.680 \AA ; C=S$ double bonds usually display values between 1.630 and $1.720 \AA$, while single bonds are longer, as expected (1.749-1.856 $\AA$ ) [32].

In compounds $7 \mathbf{b}$ and $7 \mathbf{d}$ there was a $Z \mathrm{C}(2)-\mathrm{C}(3)$ double bond, with bond lengths of 1.335 and $1.339 \AA$, respectively. Moreover, the bond length values for $S(1)-C(2)$ and $S(1)-C(9)$ in both compounds suggest an extended delocalization spanning the sulfur atom. 
Table 3. Selected geometrical parameters for compound 4 a.

\begin{tabular}{|c|c|c|c|}
\hline Bond & Bond Length [Å] & Angle & Angle $\left[{ }^{\circ}\right]$ \\
\hline$N(1)-C(2)$ & $1.360(3)$ & $\mathrm{C}(2)-\mathrm{N}(1)-\mathrm{C}(6)$ & $123.1(2)$ \\
\hline $\mathrm{N}(1)-\mathrm{C}(6)$ & $1.387(3)$ & $\mathrm{N}(3)-\mathrm{C}(2)-\mathrm{N}(1)$ & $116.4(2)$ \\
\hline$S(2)-C(2)$ & $1.680(3)$ & $N(3)-C(2)-S(2)$ & $121.9(2)$ \\
\hline $\mathrm{N}(3)-\mathrm{C}(2)$ & $1.327(3)$ & $N(1)-C(2)-S(2)$ & $121.70(18)$ \\
\hline $\mathrm{N}(3)-\mathrm{C}(4)$ & $1.469(3)$ & $\mathrm{C}(2)-\mathrm{N}(3)-\mathrm{C}(4)$ & $126.8(2)$ \\
\hline$C(4)-C(5)$ & $1.508(3)$ & $N(3)-C(4)-C(5)$ & $108.95(18)$ \\
\hline$C(5)-C(6)$ & $1.353(3)$ & $N(3)-C(4)-C(20)$ & $110.4(2)$ \\
\hline Torsion Angle (R-molecule) & Angle $\left[{ }^{\circ}\right]$ & $C(5)-C(4)-C(20)$ & $113.3(2)$ \\
\hline $\mathrm{O}(7)-\mathrm{C}(7)-\mathrm{C}(5)-\mathrm{C}(4)$ & $-11.5(4)$ & $C(6)-C(5)-C(7)$ & $125.1(2)$ \\
\hline & & $C(6)-C(5)-C(4)$ & $120.6(2)$ \\
\hline & & $C(7)-C(5)-C(4)$ & $114.2(2)$ \\
\hline & & $C(5)-C(6)-C(30)$ & $126.6(2)$ \\
\hline & & $N(1)-C(6)-C(30)$ & $113.9(2)$ \\
\hline & & $\mathrm{C}(5)-\mathrm{C}(6)-\mathrm{N}(1)$ & $119.5(2)$ \\
\hline Angles between Planes & & \multicolumn{2}{|c|}{ Angles $\left[{ }^{\circ}\right]$} \\
\hline N1-C2-N3- C4-C5-C6 & C20-...-C25 & \multicolumn{2}{|c|}{$85.68(13)$} \\
\hline N1-C2-N3- C4-C5-C6 & C30-...-C35 & \multicolumn{2}{|c|}{$66.15(17)$} \\
\hline
\end{tabular}

Table 4. Selected geometrical parameters for compounds $7 \mathrm{~b}$ and $\mathbf{7 d}$.

\begin{tabular}{|c|c|c|}
\hline Molecule & $7 \mathrm{~b}$ & $7 \mathrm{~d}$ \\
\hline \multicolumn{3}{|c|}{ Bond Length $[\AA]$} \\
\hline$S(1)-C(2)$ & $1.731(4)$ & $1.717(4)$ \\
\hline$S(1)-C(9)$ & $1.712(3)$ & $1.706(4)$ \\
\hline$C(3)-C(2)$ & $1.335(5)$ & $1.339(6)$ \\
\hline $\mathrm{N}(4)-\mathrm{C}(3)$ & $1.425(4)$ & $1.410(5)$ \\
\hline $\mathrm{N}(4)-\mathrm{C}(5)$ & $1.503(4)$ & $1.488(5)$ \\
\hline$C(5)-C(6)$ & $1.520(5)$ & $1.514(5)$ \\
\hline$C(6)-C(7)$ & $1.339(5)$ & $1.340(5)$ \\
\hline $\mathrm{N}(8)-\mathrm{C}(7)$ & $1.417(4)$ & $1.394(5)$ \\
\hline $\mathrm{N}(8)-\mathrm{C}(9)$ & $1.340(4)$ & $1.335(5)$ \\
\hline $\mathrm{N}(4)-\mathrm{C}(9)$ & $1.337(4)$ & $1.332(4)$ \\
\hline \multicolumn{3}{|c|}{ Angles $\left[{ }^{\circ}\right]$} \\
\hline $\mathrm{N}(4)-\mathrm{C}(3)-\mathrm{C}($ ring $)$ & $122.3(3)$ & $122.7(4)$ \\
\hline$C(2)-C(3)-C($ ring $)$ & $126.8(3)$ & $126.2(4)$ \\
\hline$C(3)-N(4)-C(5)$ & $123.5(3)$ & $123.9(3)$ \\
\hline $\mathrm{C}(9)-\mathrm{N}(4)-\mathrm{C}(3)$ & $113.2(3)$ & $112.6(3)$ \\
\hline $\mathrm{C}(9)-\mathrm{N}(4)-\mathrm{C}(5)$ & 121.7(3) & $123.5(3)$ \\
\hline$N(4)-C(5)-C(6)$ & $108.7(3)$ & 109.3(3) \\
\hline $\mathrm{N}(4)-\mathrm{C}(5)-\mathrm{C}($ ring $)$ & 108.7(3) & $111.2(3)$ \\
\hline$C(6)-C(5)-C($ ring $)$ & $114.0(3)$ & $110.6(3)$ \\
\hline$C(7)-C(6)-C(10)$ & $126.0(3)$ & $122.2(3)$ \\
\hline$C(7)-C(6)-C(5)$ & $123.4(3)$ & $124.0(3)$ \\
\hline$C(10)-C(6)-C(5)$ & $110.6(3)$ & 113.7(3) \\
\hline $\mathrm{C}(6)-\mathrm{C}(7)-\mathrm{N}(8)$ & 119.1(3) & $119.6(3)$ \\
\hline
\end{tabular}


Table 4. Cont.

\begin{tabular}{|c|c|c|}
\hline Molecule & $7 \mathbf{b}$ & $7 \mathrm{~d}$ \\
\hline \multicolumn{3}{|c|}{ Angles $\left[{ }^{\circ}\right]$} \\
\hline$C(6)-C(7)-C$ (ring) & 129.7(3) & 127.1(3) \\
\hline $\mathrm{N}(8)-\mathrm{C}(7)-\mathrm{C}($ ring $)$ & 111.1(3) & 113.3(3) \\
\hline $\mathrm{C}(9)-\mathrm{N}(8)-\mathrm{C}(7)$ & $120.5(3)$ & $120.8(3)$ \\
\hline $\mathrm{N}(8)-\mathrm{C}(9)-\mathrm{N}(4)$ & $122.3(3)$ & $122.7(3)$ \\
\hline$N(8)-C(9)-S(1)$ & $125.0(3)$ & $123.9(3)$ \\
\hline$N(4)-C(9)-S(1)$ & $112.7(3)$ & $113.4(3)$ \\
\hline \multicolumn{3}{|c|}{ Torsion Angles [ $\left.{ }^{\circ}\right]$} \\
\hline $\mathrm{O}(10)-\mathrm{C}(10)-\mathrm{C}(6)-\mathrm{C}(5)$ & $21.9(6)$ & $-32.7(6)$ \\
\hline \multicolumn{3}{|c|}{ Angles between planes $\left[{ }^{\circ}\right]$} \\
\hline Center ring ${ }^{a}-C 5$ phenyl ring ${ }^{b}$ & $89.49(12)$ & $83.33(11)$ \\
\hline Center ring ${ }^{a}-C 7$ phenyl ring ${ }^{c}$ & $127.57(12)$ & $74.09(14)$ \\
\hline Center ring ${ }^{a}-C 3$ phenyl ring ${ }^{d}$ & $55.68(12)$ & $56.66(12)$ \\
\hline
\end{tabular}

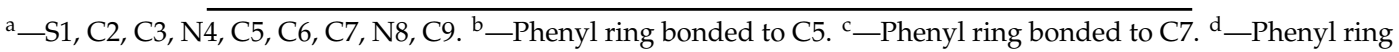
bonded to $\mathrm{C} 3$.

\subsection{Supramolecular Interactions}

\subsubsection{Hirshfeld Surface Analysis}

The 3D normalized contact distance $\left(d_{\text {norm }}\right)$ Hirshfeld surface map for compounds $4 \mathbf{a}, \mathbf{7 b}$, and $\mathbf{7 d}$ was generated using the Crystal Explorer 3.1 software [35] to investigate the intermolecular interactions in the crystal lattices. This parameter is defined as

$$
d_{\text {norm }}=\left(d_{\mathrm{i}}-r_{\mathrm{i}}^{\mathrm{vdw}}\right) / r_{\mathrm{i}}^{\mathrm{vdw}}+\left(d_{\mathrm{e}}-r_{\mathrm{e}}^{\mathrm{vdw}}\right) / r_{\mathrm{e}}^{\mathrm{vdw}}
$$

where $r_{\mathrm{i}}^{\mathrm{vdw}}$ and $r_{\mathrm{e}}^{\mathrm{vdw}}$ are the van der Waals radii of the atoms involved, $d_{\mathrm{e}}$ represents the distance from the Hirshfeld surface to the nearest atom external to the surface, and $d_{\mathrm{i}}$ represents the distance from the Hirshfeld surface to the nearest atom internal to the surface [36,37]. The value of $d_{\text {norm }}$ is positive or negative when intermolecular contacts are longer or shorter than $r^{\mathrm{vdw}}$, respectively. The Hirshfeld surface map uses a coloring code to represent the proximity of intermolecular interactions around the molecule within a network: white for $d$ around the van der Waals distance, blue for $d$ longer than van der Waals distance, and red for $d$ shorter than the van der Waals distance [38]. The 3D $d_{\text {norm }}$ Hirshfeld surface plots of the selected compounds $\mathbf{4 a}, \mathbf{7 b}$, and $\mathbf{7 d}$ included in this study are shown in Figure 3a. The plots show the main different intermolecular interactions present in each molecule. The large and deep red spots on the 3D Hirshfeld surfaces indicate the mainly strong close-contact hydrogen-bonding interactions. Additionally, the presence of weak hydrogen bonds is predicted in all molecules, involving $\mathrm{C}-\mathrm{H} \cdots \mathrm{X}(\mathrm{X}=\mathrm{O}, \mathrm{N}, \mathrm{S}, \mathrm{Br})$ interactions. Other possible intermolecular interactions appear as lighter red regions (Figure 3a). The combination of $d_{\mathrm{e}}$ and $d_{\mathrm{i}}$ in the form of two-dimensional (2D) fingerprint plots provides a summary of the intermolecular contacts in the crystal [37]. Thus, the histograms in Figure $3 \mathrm{~b}$ present the summary of the percentage contributions of the various types of potential interactions. For all compounds, the major contribution was related to the proximity-induced $\left(\mathrm{H}^{\cdots} \mathrm{H}\right)(48-54 \%)$ and $(\mathrm{C} \cdots \mathrm{H})$ interactions $(15.4-19.9 \%)$ (Figure $\left.3 b\right)$. The major contacts expected in compound 4a were $\mathrm{N}-\mathrm{H} \cdots \mathrm{S}(13.8 \%)$ and $\mathrm{N}-\mathrm{H} \cdots \mathrm{O}(7.8 \%)$. Noteworthy, in the case of compounds $7 \mathbf{b}$ and $7 \mathbf{d}$, was the prediction of strong $\mathrm{Br}^{-} \cdots \mathrm{H} 8-\mathrm{N} 8$ hydrogen bond contributions (11.4 and 9.8\%, respectively), together with weak $\mathrm{C}-\mathrm{H} \cdots$ O hydrogen bonds (10.7 and $8.7 \%$, respectively) (Figure $3 \mathrm{~b}$ ). 

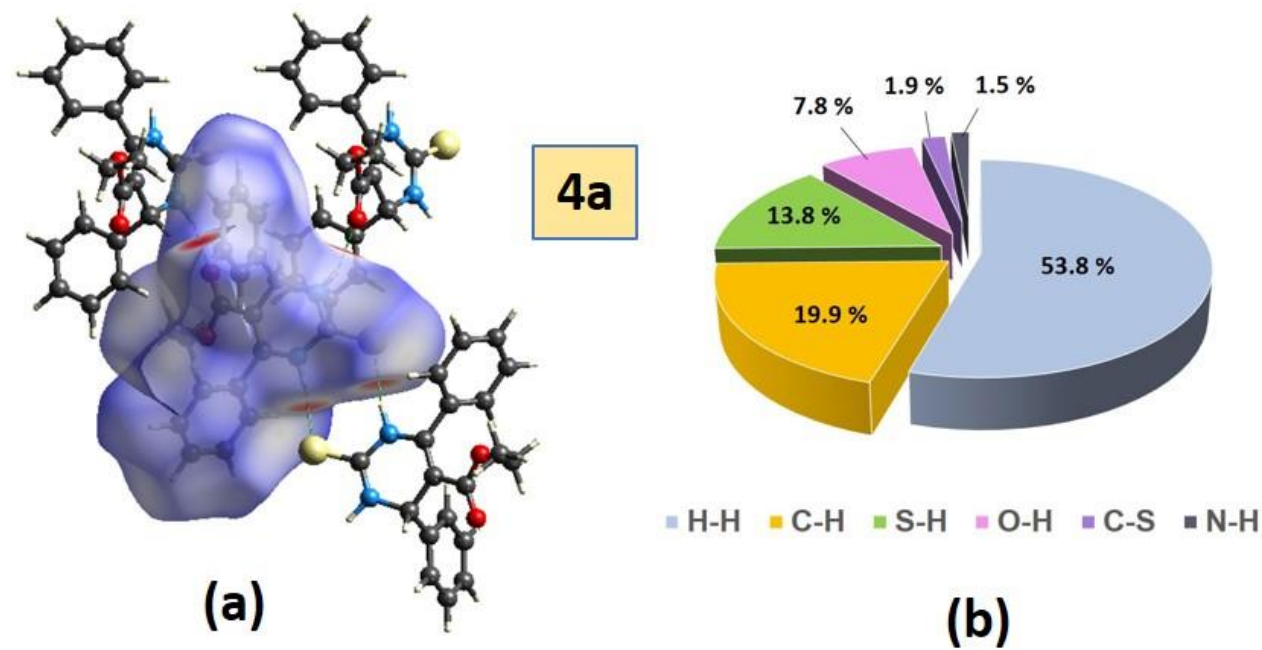

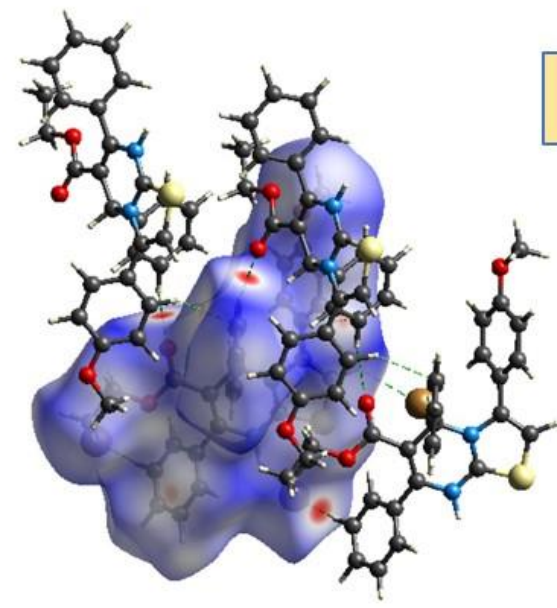

(a)

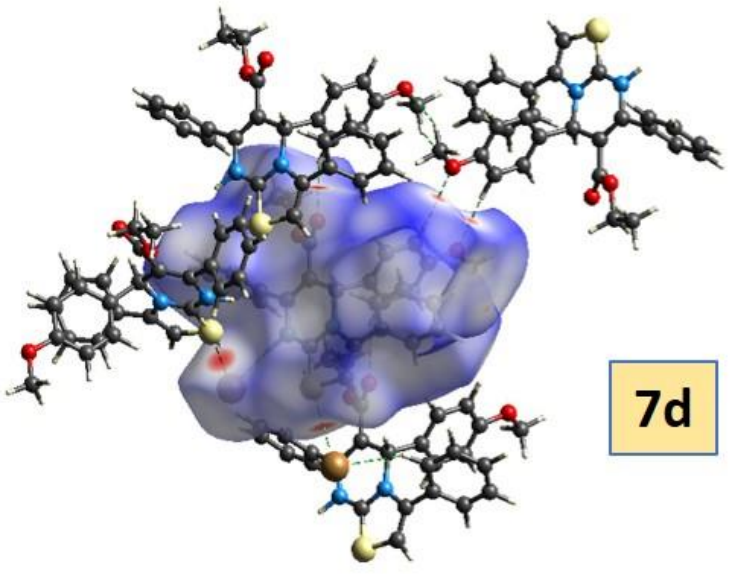

(a)

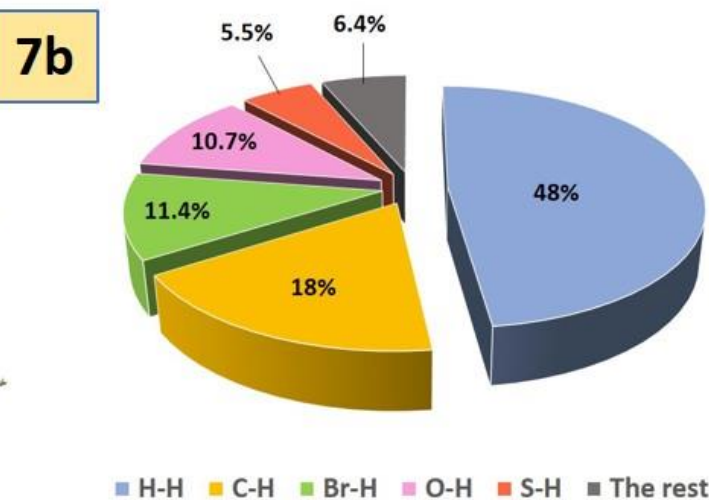

(b)

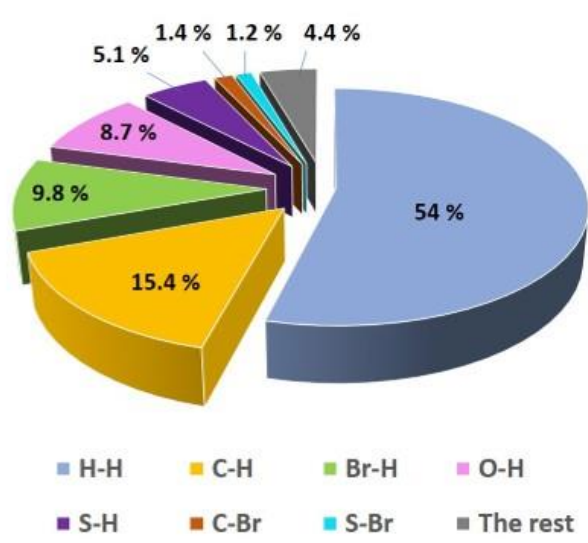

(b)

Figure 3. (a) 3D Hirshfeld surfaces mapped with $d_{\text {norm }}$; red colored regions show shorter contacts; (b) histograms showing the percentage contributions of the various types of interactions predicted for compounds $4 \mathbf{a}, 7 \mathbf{b}$, and $7 \mathrm{~d}$. 


\subsubsection{Crystal Packings}

Analysis of the crystal packing for these compounds confirmed that they are all racemic mixtures, as expected from the lack of stereoselectivity of the reaction conditions involved in their synthesis. The interactions detected on each compound using Platon and visualized using Mercury were consistent with the Hirshfeld analysis results.

Compound 4a was found to have four molecules in the unit cell, two of isomer $R$ and two of isomer $S$. The molecule has a good hydrogen donor system that formed classical hydrogen bonds: $\mathrm{N}(3)-\mathrm{H}(3 \mathrm{~N}) \cdots \mathrm{O}(7)$ between molecules inside the unit cell and an $\mathrm{R}^{2}{ }_{2}(8)$ synthon involving $\mathrm{N}(1)-\mathrm{H}(1 \mathrm{~N}) \cdots \mathrm{S}(2)$ interactions with molecules outside the unit cell (Figure 4 and Table 5).
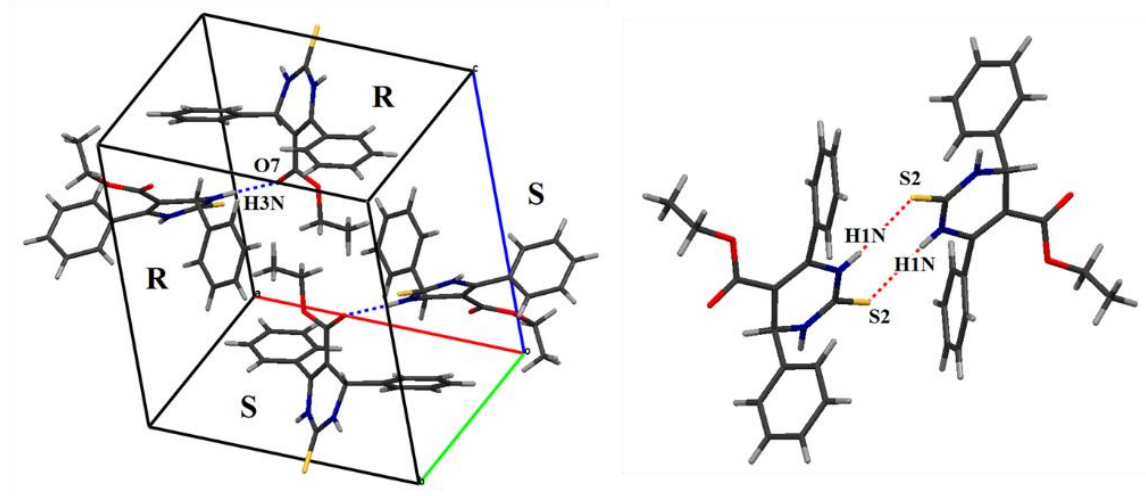

Figure 4. Hydrogen bonds in compound 4a: Inside the unit cell (left) and with other molecules outside the unit cell (right).

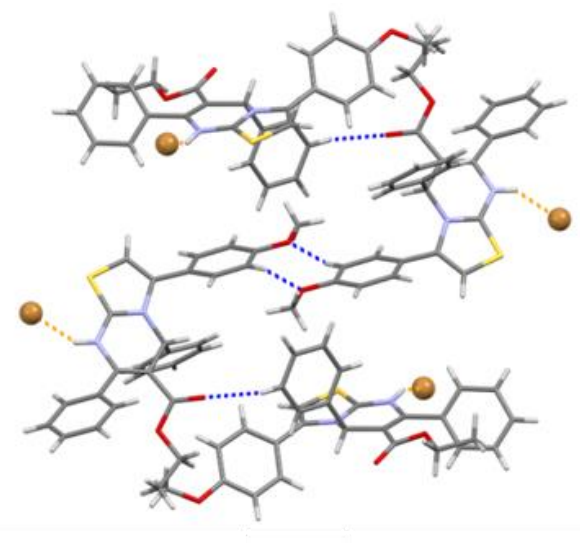

$7 b$

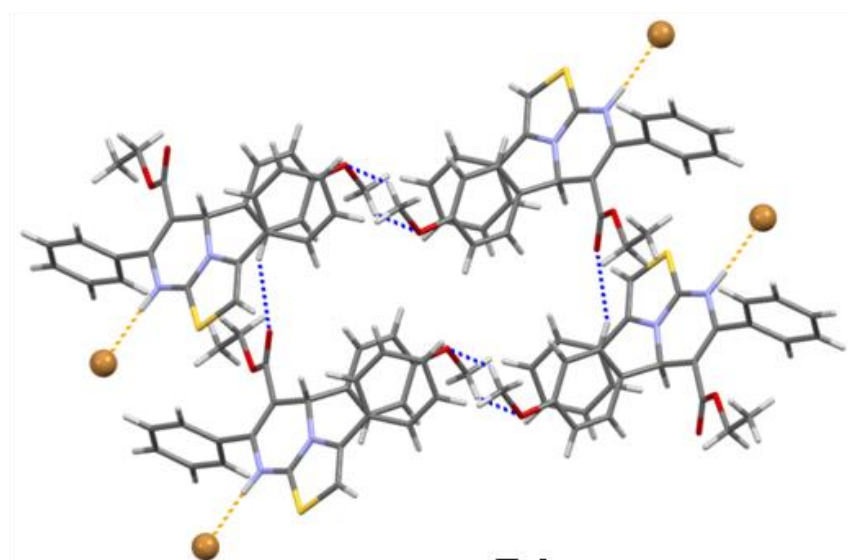

$7 d$

Figure 5. Main supramolecular interactions in compounds $7 \mathbf{b}$ and $7 \mathbf{d}$ (classical hydrogen bonds are represented in orange, weak hydrogen bonds in blue).

Due to the presence of $\mathrm{Br}^{-}$ions, the crystal structure of compound $\mathbf{7 d}$ was dominated by the strong anion $\cdots \mathrm{H}-\mathrm{N}$ hydrogen bond with the protonated $\mathrm{N} 8$, but it also included weak $\mathrm{C}-\mathrm{H} \cdots \mathrm{O}$

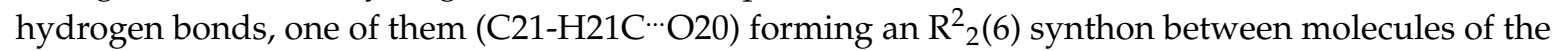
two stereoisomers. A similarly strong $\mathrm{Br}^{-\cdots} \mathrm{H} 8 \mathrm{-N} 8$ hydrogen bond was formed in compound $7 \mathbf{b}$, in which case the anion was also involved in a weak hydrogen bond, acting as a bridge between two cations of the same enantiomer. $\mathrm{R}^{2}{ }_{2}(8)$ synthons were formed by C-H $\cdots$ O hydrogen bonds between $R$ and $S$ - molecules (Figure 5 and Table 5). 
Table 5. Interaction parameters for compounds $4 \mathbf{a}, 7 \mathbf{b}$, and $7 \mathrm{~d}$.

\begin{tabular}{|c|c|c|c|c|}
\hline D-H $\cdots A$ & $\mathbf{H}^{\cdots} \mathbf{A}[\AA ̊]$ & $\mathbf{D} \cdots \mathbf{A}[\AA ̊]$ & $\mathrm{D}-\mathrm{H}^{\cdots} \mathbf{A}\left[\left[^{\circ}\right]\right.$ & Symmetry Operation \\
\hline \multicolumn{5}{|l|}{ Compound 4a } \\
\hline $\mathrm{N}(3)-\mathrm{H}(3 \mathrm{~N}) \cdots \mathrm{O}(7)$ & 2.02 & $2.872(2)$ & 159 & $\frac{1}{2}-x, 1 / 2+y, 1 / 2-z$ \\
\hline $\mathrm{N}(1)-\mathrm{H}(1 \mathrm{~N}){ }^{\cdots} \mathrm{S}(2)$ & 2.52 & $3.337(2)$ & 173 & $-\mathrm{x}, 1-\mathrm{y}, 1-\mathrm{z}$ \\
\hline \multicolumn{5}{|l|}{ Compound 7b } \\
\hline $\mathrm{N} 8-\mathrm{H} 8 \cdots \mathrm{Br}^{\mathrm{a}}$ & 2.48 & $3.199(3)$ & 141 & $\mathrm{x}, \mathrm{y}, \mathrm{z}$ \\
\hline $\mathrm{C} 32-\mathrm{H} 32 \cdots \mathrm{Br} 1^{\mathrm{b}}$ & 2.81 & $3.742(4)$ & 175 & $x,-1+y, z$ \\
\hline 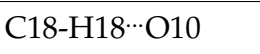 & 2.49 & $3.397(6)$ & 166 & $1-x, 1 / 2+y, 1 / 2-z$ \\
\hline $\mathrm{C} 24-\mathrm{H} 24 \cdots \mathrm{O} 26$ & 2.60 & $3.507(6)$ & 166 & $1-x, 1-y, 1-z$ \\
\hline \multicolumn{5}{|l|}{ Compound 7d } \\
\hline N8-H8 $\cdots$ Br1 $^{\mathrm{a}}$ & 2.28 & $3.167(3)$ & 165 & $\mathrm{x}, \mathrm{y}, \mathrm{z}$ \\
\hline 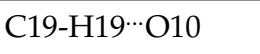 & 2.51 & $3.372(5)$ & 153 & $x,-1+y, z$ \\
\hline $\mathrm{C} 21-\mathrm{H} 21 \mathrm{C} \cdots \mathrm{O} 20$ & 2.66 & $3.456(6)$ & 140 & $2-x,-y, 1-z$ \\
\hline
\end{tabular}

\subsection{Molecular Docking Studies to Human Acetylcholinesterase}

In order to investigate the affinities of the fused thiazolo[3,2-a]pyrimidines $7 \mathbf{a}-\mathbf{d}$ toward human acetylcholinesterase ( $h \mathrm{AChE}$ ), we started by performing molecular docking simulations of the target compounds into the active site gorge of $h \mathrm{AChE}$ (PDB ID: $4 \mathrm{~m} 0 \mathrm{f}$, chain A), using Autodock Vina software [39]. Docking simulations were performed concomitantly with the known $h \mathrm{AChE}$ inhibitors, donepezil, tacrine, and rivastigmine, used as reference drugs for comparative purposes. The results for the binding free energies of all compounds investigated are summarized in Figure 6.

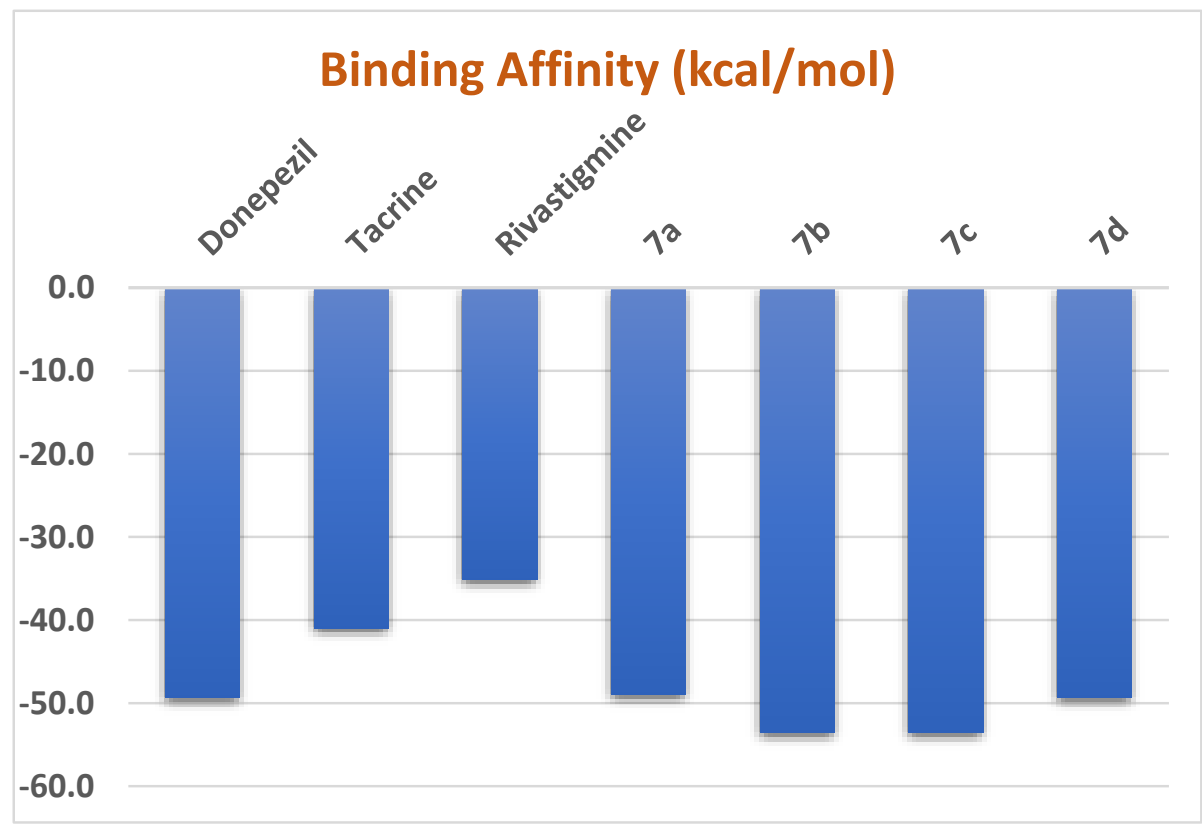

Figure 6. Comparison of the binding free energies of compounds $7 \mathbf{a}-\mathbf{d}$ and the reference $h \mathrm{AChE}$ inhibitors donepezil, tacrine, and rivastigmine to the active site gorge of $h \mathrm{AChE}$.

Molecular docking indicated good binding to $h \mathrm{AChE}$, with all compounds $7 \mathbf{a}-\mathbf{d}$ binding equally or more strongly than any of the positive controls, which suggests that the compounds are potentially powerful AChE inhibitors. We further probed the structural features responsible for the strong binding to the enzyme. As representative examples, Figure $7 \mathrm{~A}, \mathrm{~B}$ displays the docking poses for compounds $\mathbf{7 b}$ and $\mathbf{7 d}$ (cf. next paragraph). 


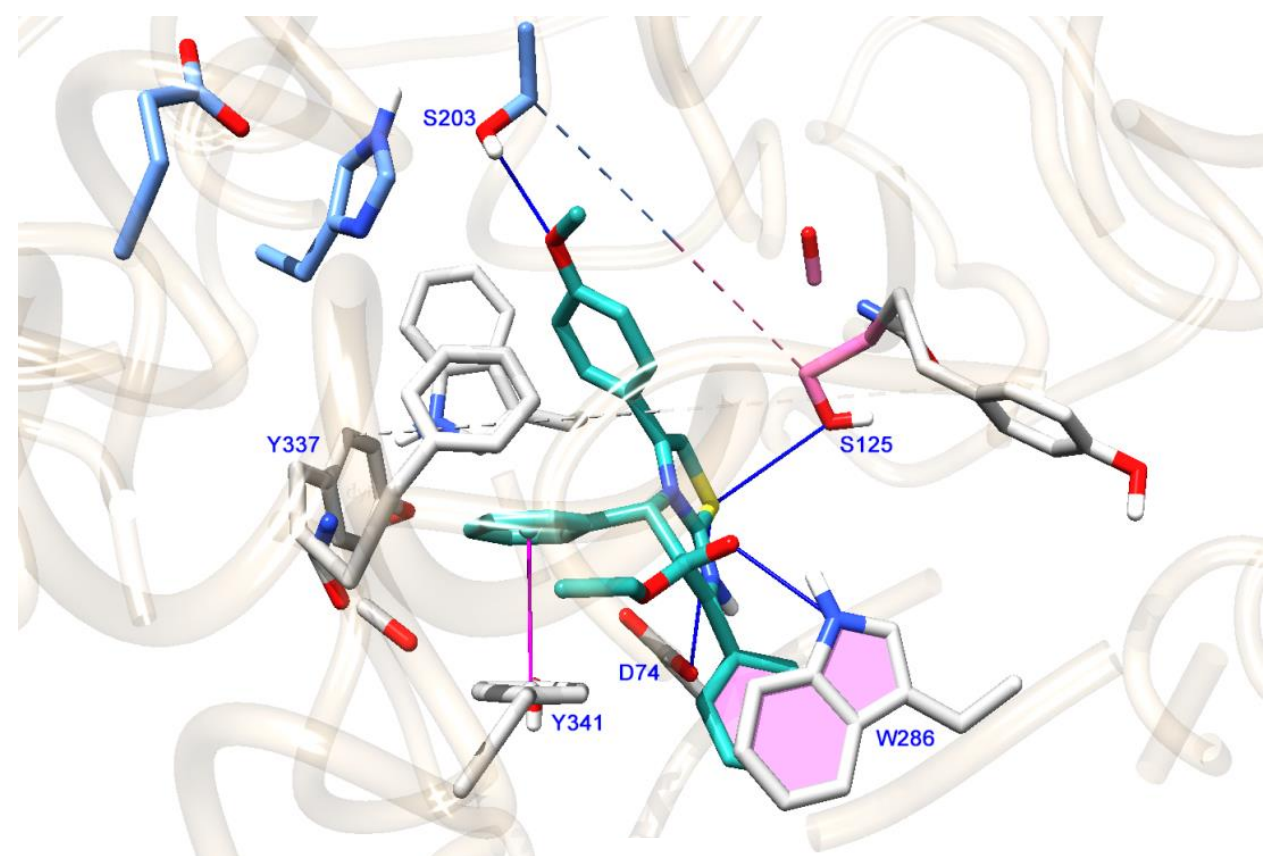

(A)

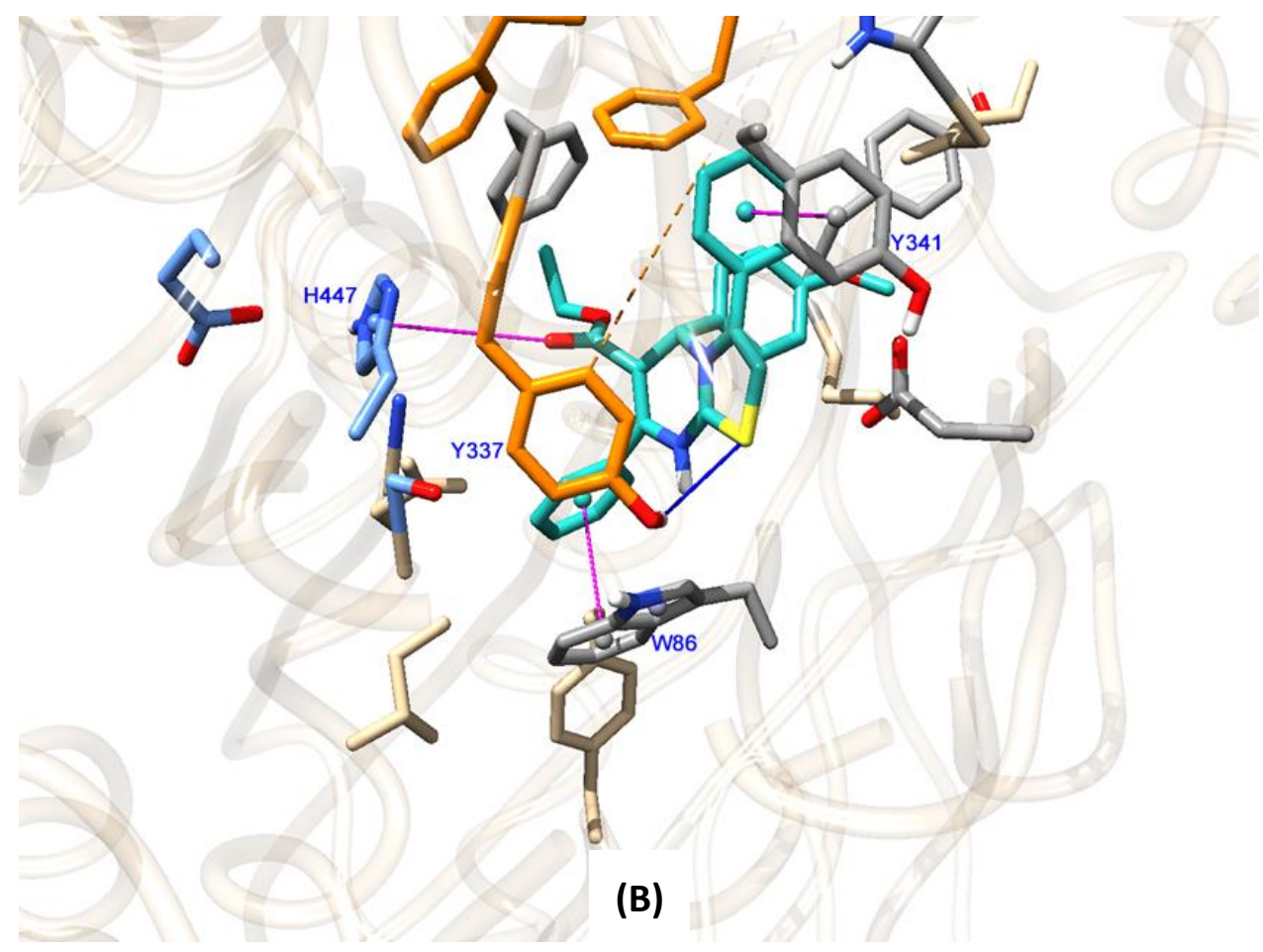

Figure 7. (A) and (B) A close view of $\mathbf{7 b}$ and $\mathbf{7 d}$ docked into the active site gorge of human AChE. Catalytic residues are shown in blue and the peripheral anionic site residues are shown in grey; the ligands are shown in light blue.

A number of electrostatic interactions were found between $7 \mathbf{b}$ and the side chain $\mathrm{O}$ atoms of Ser125 (at $4.0 \AA$ ) and of Asp74 (at $4.0 \AA$ ), and between the keto O atom of the ligand and the side chain $\mathrm{N}$ atom of Trp286 (at $3.0 \AA$ ). An $\mathrm{H}$ bond is also possible between the latter atom pair (with a $\mathrm{H}$-acceptor distance of $2.1 \AA$ and a donor-acceptor distance of $3.0 \AA$ ), albeit at a donor-H-acceptor angle on the lower limit of the allowed region $\left(135^{\circ}\right)$. Aromatic interactions are also quite evident between the 
ligand and nearby amino acid residues, in particular a $\pi-\pi$ stacking involving the planes of the Trp286 side-chain and of one of the ligand aromatic rings (at a $3.9 \AA$ A distance, with an inter-plane angle of $\left.9.3^{\circ}\right)$. Another $\pi-\pi$ stacking between the aromatic plane of Tyr341 and an aromatic plane of the ligand is also possible (at a $3.7 \AA$ distance, with an inter-plane angle of $2.1^{\circ}$ ).

Concerning ligand $\mathbf{7 d}$, aromatic interactions are also evident between the ligand aromatic planes and the aromatic planes of Tyr341 (at a $4.3 \AA$ ) and Trp86 (at $4.3 \AA$ ); an anion- $\pi$ interaction is also likely to occur between the carbonyl $\mathrm{O}$ atom of the ligand and the imidazole ring of His 447 . Various electrostatic interactions are also possible between the ligand and protein amino acid residues, noticeably from the ligand $\mathrm{S}$ atom to the phenolic $\mathrm{O}$ atom of Tyr337 (at a $4.0 \AA$ Aistance).

Although the poses differ between the compounds, the two panels in Figure 7 show both hydrophobic and hydrogen bond interactions with amino acids located in the peripheral anionic site (PAS) at the mouth of the gorge. PAS is a well-known substrate-binding site in AChE and binding of ligands at this location has been amply reported to affect the catalytic activity of the enzyme, by blocking access to the catalytic site and/or inducing an allosteric alteration of the catalytic triad conformation and efficiency [40-42].

\subsection{In Vitro hAChE Inhibition}

In view of the encouraging results obtained in the in silico study, compounds $7 \mathbf{a}-\mathbf{d}$ were evaluated for their $h \mathrm{AChE}$ inhibitory activity at up to $50 \mu \mathrm{M}$ concentrations using a standard Ellman-based colorimetric protocol [43]. For comparative purposes, the powerful $h \mathrm{AChE}$ inhibitor methyl paraoxon was used as positive control.

As shown in Figure 8, all compounds demostrated $h \mathrm{AChE}$ inhibitory activities at the micromolar $(\mu \mathrm{M})$ level, ranging from $73-77.5 \%$ at $10 \mu \mathrm{M}$ to $59-74 \%$ at $5 \mu \mathrm{M}$; at the same concentrations, the positive control inhibitor yielded approximately $100 \%$ inhibition. $\mathrm{IC}_{50}$ values for $h \mathrm{AChE}$ inhibition, obtained for compounds $\mathbf{7 a}-\mathbf{c}$, were approximately $1 \mu \mathrm{M}(\mathbf{7 a}, 1.59 \mu \mathrm{M} ; \mathbf{7 b}, 1.00 \mu \mathrm{M} ; \mathbf{7 c}, 1.17 \mu \mathrm{M})$, as compared to $4.9 \mathrm{nM}$ for the positive control, methyl paraoxon, under the conditions of the assay. Likewise, $h \mathrm{AChE}$ inhibitors such as donepezil, rivastigmine, and tacrine are reported to have $\mathrm{IC}_{50}$ values in the low nanomolar range, under optimal assay conditions [44].

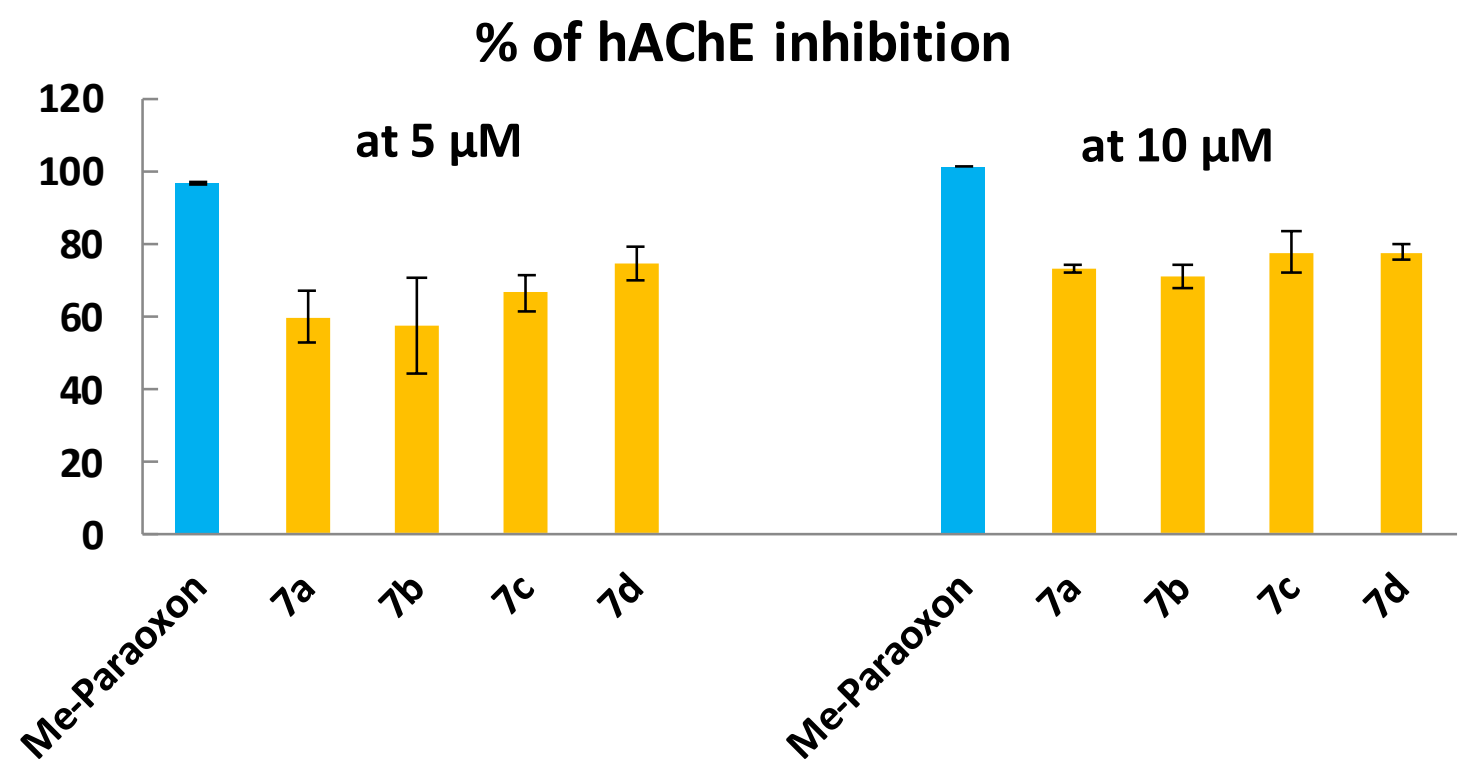

Figure 8. Experimental in vitro $h \mathrm{AChE}$ inhibition activities of the fused thiazolo[3,2-a]pyrimidines $7 \mathrm{a}-\mathbf{d}$ and the positive control, methyl paraoxon, at 5 and $10 \mu \mathrm{M}$. The data are expressed as average \pm standard deviation of two independent experiments. 


\section{Materials and Methods}

All reagents were purchased from commercial sources and used without further purification, unless stated otherwise. Whenever necessary, solvents were dried by standard methods [45]. Melting temperatures were measured with a Leica Galen III hot stage apparatus and are uncorrected.

${ }^{1} \mathrm{H}-\mathrm{NMR}$ spectra were recorded on a Bruker Avance III 400 spectrometer, operating at $400 \mathrm{MHz}$. ${ }^{13} \mathrm{C}$-NMR spectra were recorded on the same instrument, operating at $100.62 \mathrm{MHz}$. Chemical shifts are reported in ppm downfield from tetramethylsilane and coupling constants $(J)$ are reported in Hz. Resonance and structural assignments (indicated using the IUPAC nomenclature system) were based on the analysis of coupling patterns, including the ${ }^{13} \mathrm{C}-{ }^{1} \mathrm{H}$ coupling profiles obtained from heteronuclear single quantum coherence (HSQC) and heteronuclear multiple bond correlation (HMBC) experiments, performed with standard pulse programs. The abbreviations $\mathrm{Ph}$ and Ar represent phenyl and aryl groups, respectively.

Low resolution mass spectra (MS) were recorded on an LCQ Fleet ion trap mass spectrometer equipped with an electrospray (ESI) ion source (Thermo Scientific). The mass spectrometer was operated in the ESI positive ion mode, with the following optimized parameters: Ion spray voltage, $+4.5 \mathrm{kV}$; capillary voltage, $16 \mathrm{~V}$; tube lens offset, $-63 \mathrm{~V}$; sheath gas $\left(\mathrm{N}_{2}\right), 80$ arbitrary units; auxiliary gas $\left(\mathrm{N}_{2}\right)$, five arbitrary units; capillary temperature, $30{ }^{\circ} \mathrm{C}$. Spectra typically correspond to the average of 20-35 scans and were recorded in the range between 100 and $1500 \mathrm{Da}$. Tandem mass spectra (collision-induced dissociation experiments) were obtained with an isolation window of 4-9 Da, a $20-30 \%$ relative collision energy, and an activation energy of $30 \mathrm{~ms}$. Data acquisition and processing were performed using the Xcalibur software.

High-resolution mass spectra (HRMS) were obtained on a Bruker Impact II quadrupole time-of-flight mass spectrometer (Bruker Daltoniks). Aliquots $(10 \mu \mathrm{L})$ of the samples dissolved in methanol were analyzed by flow injection analysis (FIA) using an isocratic gradient (50 A:50 B) of $0.1 \%$ formic acid in water (A) and $0.1 \%$ of formic acid in acetonitrile (B), at a flow rate of $10 \mu \mathrm{Lmin}^{-1}$ over $15 \mathrm{~min}$. The mass spectrometer was operated in the ESI positive ion mode and in the high-resolution mode. The following optimized parameters were used: Capillary voltage: $+4.5 \mathrm{kV}$; end plate offset: $-500 \mathrm{~V}$; nebulizer: $40 \mathrm{psi}$; dry gas: $4.0 \mathrm{~L} \cdot \mathrm{min}^{-1}$; dry heater: $200{ }^{\circ} \mathrm{C}$; $\mathrm{m} / \mathrm{z} 100-2000$; acquisition mode: full scan acquisition with a scan rate of $1.0 \mathrm{~Hz}$. Prior to analysis, the mass scale was calibrated by infusion of ESI low concentration tune mix at a $15 \mu \mathrm{L} \cdot \mathrm{min}^{-1}$ flow rate. Recalibration of acquired data was performed via lock mass internal calibration (1221.9906) located within the source. Data processing was performed using the Data Analysis 4.1 software.

\subsection{X-Ray Crystallographic Analysis}

X-ray crystallographic data for compounds $4 \mathbf{a}, 7 \mathbf{b}$, and $\mathbf{7 d}$ were collected from single crystals using an area detector diffractometer (Bruker AXS-KAPPA APEX II, Madison, WI, USA) at room temperature and graphite-monochromated Mo $\mathrm{K} \alpha(\lambda=0.71073 \AA)$ radiation. Cell parameters were retrieved using Bruker SMART software and refined with Bruker SAINT [46] on all observed reflections. Absorption corrections were applied using SADABS [47]. The structures were solved by direct methods using SHELXT [48] and refined with full-matrix least-squares refinement against $\mathrm{F}^{2}$ using SHELXL [49]. All the programs are included in the WINGX package (version 2014.01) [50]. All non-hydrogen atoms were refined anisotropically, and the hydrogen atoms were inserted in idealized positions, riding on the parent $C$ atom, except for those connected to nitrogen atoms, placed according to the electron density maps. Drawings were made using Mercury CSD 3.9 (Build RC1) [51]. Geometrical parameters such as angles between planes and torsion angles were calculated using Olex ${ }^{2}-1.2 .9$ [52], while intermolecular interactions were determined using Platon 30715 [53] and visualized using Mercury. Despite several attempts, good quality crystals of compound $\mathbf{7 d}$ could not be obtained, a circumstance that is reflected in the refinement of the crystal structure. Relevant details of the X-ray data analysis are displayed in Table 6 (cf. X-ray diffraction studies section). 
Table 6. Structure refinement data of compounds $4 a, 7 b$, and $7 d$.

\begin{tabular}{cccc}
\hline Compound & 4a & 7b & 7d \\
\hline Absorption coefficient $\left(\mathrm{mm}^{-1}\right)$ & 0.194 & 1.694 & 1.680 \\
\hline $\mathrm{F}(000)$ & 712 & 1128 & 1128 \\
\hline Crystal size $(\mathrm{mm})$ & $0.30 \times 0.15 \times 0.15$ & $0.200 \times 0.100 \times 0.040$ & $0.150 \times 0.060 \times 0.040$ \\
\hline$\theta$ range $\left(^{\circ}\right)$ & 2.776 to 26.497 & 2.808 to 26.358 & 2.873 to 26.440 \\
\hline Index ranges & $-16 \leq \mathrm{h} \leq 16$, & $-18 \leq \mathrm{h} \leq 18$, & $-16 \leq \mathrm{h} \leq 16$, \\
& $-10 \leq \mathrm{k} \leq 10$, & $-10 \leq \mathrm{k} \leq 10$, & $-8 \leq \mathrm{k} \leq 8$, \\
& $-20 \leq 1 \leq 20$ & $-19 \leq 1 \leq 26$ & $-35 \leq 1 \leq 35$ \\
\hline Reflections collected & 49,517 & 14,223 & 99,174 \\
\hline Independent reflections & $3618[\mathrm{R}(\mathrm{int})=0.0299]$ & $5233[\mathrm{R}(\mathrm{int})=0.0695]$ & $5395[\mathrm{R}(\mathrm{int})=0.2244]$ \\
\hline Completeness to $\Theta$ max $(\%)$ & 98.4 & 99.6 & 99.9 \\
\hline Data/restraints/parameters & $3618 / 1 / 219$ & $5233 / 0 / 316$ & $5395 / 1 / 320$ \\
\hline Goodness-of-fit on F2 & 1.051 & 0.955 & 1.054 \\
\hline Final R indices $[\mathrm{I}>$ 2sigma(I)] & $\mathrm{R} 1=0.0711$. & $\mathrm{R} 1=0.0491$, & $\mathrm{R} 1=0.0491$, \\
& $\mathrm{wR} 2=0.1922$ & $\mathrm{wR} 2=0.1000$ & wR2 $=0.0873$ \\
\hline R indices (all data) & $\mathrm{R} 1=0.0842$, & $\mathrm{R} 1=0.1095$, & $\mathrm{R} 1=0.1299$, \\
& wR2 $=0.2063$ & $\mathrm{wR} 2=0.1210$ & wR2 $=0.1163$ \\
\hline Extinction coefficient & $\mathrm{n} / \mathrm{a}$ & $\mathrm{n} / \mathrm{a}$ & $\mathrm{n} / \mathrm{a}$ \\
\hline Largest diff. peak/hole $\left(\mathrm{e} . \AA^{-3}\right)$ & $0.872 /-0.992$ & 0.300 and -0.501 & 0.610 and -0.503 \\
\hline
\end{tabular}

Crystallographic data for compounds $\mathbf{4 a}, \mathbf{7 b}$, and $\mathbf{7 d}$ were deposited with the Cambridge Crystallographic Data Centre (CCDC 1496341, 1911742, and 1911743) and can be obtained free of charge from: CCDC, 12 Union Road, Cambridge CB2 1EZ, UK (Fax: 44-1223-226033; e-mail: deposit@ccdc.cam.ac.uk) or http://www.ccdc.cam.ac.uk/deposit.

\subsection{General Procedure for the Preparation of DHPMs $\mathbf{4 a}, \mathbf{b}$}

The DHPMs $\mathbf{4 a}, \mathbf{b}$ were prepared as previously described [31]. Briefly, a mixture of aldehyde ( $1 \mathrm{mmol})$, ethyl benzoylacetate $(1 \mathrm{mmol})$, thiourea $(1 \mathrm{mmol})$, and quartz $(0.5 \mathrm{~g})$ in ethanol $(15 \mathrm{~mL})$ was refluxed for $3 \mathrm{~h}$. After completion of the reaction, as monitored by thin layer chromatography (tlc), the catalyst was filtered off and the solution was kept overnight. The precipitate formed on setting was filtered under suction and then recrystallized from ethanol to afford the pure product $\mathbf{4 a}, \mathbf{b}$.

\subsubsection{Ethyl 4,6-diphenyl-2-thioxo-1,2,3,4-tetrahydropyrimidine-5-carboxylate (4a)}

Yield 85\%; $R_{\mathrm{f}} 0.54$ (tlc, silica, 2:1 hexane:ethyl acetate); mp 193-195 ${ }^{\circ} \mathrm{C}$ [lit [54], $192{ }^{\circ} \mathrm{C}$; ${ }^{1} \mathrm{H}-\mathrm{NMR}$ $\left(400 \mathrm{MHz}\right.$, DMSO- $\left.d_{6}\right) \delta 0.73\left(\mathrm{t}, 3 \mathrm{H}, J\right.$ 7.0, $\left.\mathrm{CH}_{3} \mathrm{CH}_{2} \mathrm{O}\right), 3.74\left(\mathrm{q}, 2 \mathrm{H}, J\right.$ 7.1, $\left.\mathrm{CH}_{3} \mathrm{CH}_{2} \mathrm{O}\right), 5.27(\mathrm{~d}, 1 \mathrm{H}, J 3.4$, C4-H), 7.30-7.41 (m, 10 H, Ph-H), 9.75 (s, 1H, exchangeable, N3-H), 10.47 (s, 1H, exchangeable, N1-H); ${ }^{13} \mathrm{C}-\mathrm{NMR}\left(400 \mathrm{MHz}, \mathrm{DMSO}-d_{6}\right) \delta 13.31\left(\mathrm{CH}_{3}\right), 54.08(\mathrm{C} 4), 59.44\left(\mathrm{CH}_{2}\right), 101.82(\mathrm{C} 5), 126.38,127.68$, 127.78, 128.63, 128.66, 129.08 (Ph-CH), 133.98, 143.00 (Ph- $\left.\mathrm{C}_{\text {quat }}\right), 145.79$ (C6), 164.87 (C=O), 174.51 (C=S); ESI-MS $m / z 339$ [MH] ${ }^{+}$; ESI-MS/MS (339) $m / z$ 322, 280, 276, 263, 234, 219; HRMS (ESI-TOF) Calcd for $\mathrm{C}_{19} \mathrm{H}_{19} \mathrm{~N}_{2} \mathrm{O}_{2} \mathrm{~S}, m / z 339.1162\left([\mathrm{MH}]^{+}\right)$, Found $339.1154(\Delta=-2.4 \mathrm{ppm})$.

\subsubsection{Ethyl 4-(4-methoxyphenyl)-6-phenyl-2-thioxo-1,2,3,4-tetrahydropyrimidine-5-carboxylate (4b)}

Yield 68\%; $R_{\mathrm{f}} 0.43$ (tlc, silica, 2:1 hexane:ethyl acetate); mp 130-132 ${ }^{\circ} \mathrm{C} ;{ }^{1} \mathrm{H}-\mathrm{NMR}(400 \mathrm{MHz}$, DMSO- $\left.d_{6}\right) \delta 0.74\left(\mathrm{t}, 3 \mathrm{H}, J\right.$ 7.0, $\left.\mathrm{CH}_{3} \mathrm{CH}_{2} \mathrm{O}\right), 3.73\left(\mathrm{q}, 2 \mathrm{H}, J\right.$ 7.0, $\left.\mathrm{CH}_{3} \mathrm{CH}_{2} \mathrm{O}\right), 3.75\left(\mathrm{~s}, 3 \mathrm{H}, \mathrm{OCH}_{3}\right), 5.22$ $(\mathrm{s}, 1 \mathrm{H}, \mathrm{C} 4-\mathrm{H}), 6.96\left(\mathrm{~d}, 2 \mathrm{H}, J_{\text {ortho }} 7.8,4-\mathrm{OCH}_{3} \mathrm{Ph}-\mathrm{C} 3, \mathrm{C} 5-\mathrm{H}\right), 7.30(\mathrm{~m}, 5 \mathrm{H}, \mathrm{Ph}-\mathrm{H}), 7.40\left(\mathrm{~d}, 2 \mathrm{H}, J_{\text {ortho }}\right.$ 7.8, 4-OCH $\left.{ }_{3} \mathrm{Ph}-\mathrm{C} 2, \mathrm{C} 6-\mathrm{H}\right), 9.67$ (s, 1H, exchangeable, N3-H), 10.40 (s, 1H, exchangeable, N1-H); ${ }^{13} \mathrm{C}-\mathrm{NMR}\left(400 \mathrm{MHz}, \mathrm{DMSO}-d_{6}\right) \delta 13.30\left(\mathrm{CH}_{3}\right), 53.52(\mathrm{C} 4), 55.08\left(\mathrm{OCH}_{3}\right), 59.44\left(\mathrm{CH}_{2}\right), 102.08(\mathrm{C} 5)$, $114.0\left(4-\mathrm{OCH}_{3} \mathrm{Ph}-\mathrm{C} 3, \mathrm{C} 5\right), 127.60$ (4-OCH $\left.{ }_{3} \mathrm{Ph}-\mathrm{C} 2, \mathrm{C} 6\right), 127.63,128.60,129.08$ (Ph-CH), 134.04 (Ph-C1), 
135.16 (4-OCH ${ }_{3} \mathrm{Ph}-\mathrm{C1}$ ), 145.46 (C6), 158.82 (4-OCH$\left.{ }_{3} \mathrm{Ph}-\mathrm{C} 4\right), 164.85$ (C=O), 174.30 (C=S); ESI-MS m/z 369 [MH] ${ }^{+}$; ESI-MS/MS (369) $\mathrm{m} / \mathrm{z}$ 352, 310, 293, 264, 249, 217; HRMS (ESI-TOF) Calcd for $\mathrm{C}_{20} \mathrm{H}_{21} \mathrm{~N}_{2} \mathrm{O}_{3} \mathrm{~S}$, $\mathrm{m} / \mathrm{z} 369.1273\left([\mathrm{MH}]^{+}\right)$, Found $369.1267(\Delta=-1.6 \mathrm{ppm})$.

\subsubsection{Synthesis of the Thiazolo[3,2-a]pyrimidine Bromides $7 \mathbf{a}-\mathbf{d}$ and the Neutralized Compound 9}

A mixture of each DHPM $4 \mathbf{a}, \mathbf{b}(1 \mathrm{mmol})$ and the appropriate phenacyl bromide derivative 5 $(1 \mathrm{mmol})$ in ethanol was heated under reflux for $12 \mathrm{~h}$. The reaction mixture was monitored by tlc. The solvent was removed under reduced pressure. The residue was washed several times with a mixture of $n$-hexane:ethyl acetate 2:1. After washing, the final precipitate was dried to give the bromide salt of thiazolo[3,2-a]pyrimidines $\mathbf{7 a}-\mathbf{d}$ with good yields. Compound $\mathbf{7 b}$ was neutralized to the corresponding product 9 using a saturated sodium carbonate solution.

\subsubsection{6-(Ethoxycarbonyl)-3,5,7-triphenyl-5H-thiazolo[3,2-a]pyrimidin-8-ium bromide (7a)}

Yield $80 \% ; R_{\mathrm{f}} 0.44$ (tlc, silica, 2:1 hexane:ethyl acetate); mp 205-207 ${ }^{\circ} \mathrm{C} ;{ }^{1} \mathrm{H}-\mathrm{NMR}\left(400 \mathrm{MHz}, \mathrm{CDCl}_{3}\right)$ $\delta 0.78\left(\mathrm{t}, 3 \mathrm{H}, J\right.$ J 7.0, $\left.\mathrm{CH}_{3} \mathrm{CH}_{2} \mathrm{O}\right), 3.85\left(\mathrm{q}, 2 \mathrm{H}, J\right.$ 7.0, $\left.\mathrm{CH}_{3} \mathrm{CH}_{2} \mathrm{O}\right), 6.44(\mathrm{~s}, 1 \mathrm{H}, \mathrm{C} 5-\mathrm{H}), 6.80(\mathrm{~d}, 2 \mathrm{H}, J$ 7.5, $\mathrm{Ph}-\mathrm{CH}), 7.14-7.55(\mathrm{~m}, 14 \mathrm{H}, \mathrm{Ph}-\mathrm{CH}$ and $\mathrm{C} 2-\mathrm{H}), 13.40\left(\mathrm{br}, 1 \mathrm{H}, \mathrm{N}^{+} 8-\mathrm{H}\right) ;{ }^{13} \mathrm{C}-\mathrm{NMR}\left(400 \mathrm{MHz}, \mathrm{CDCl}_{3}\right)$ $\delta 13.43\left(\mathrm{CH}_{3} \mathrm{CH}_{2} \mathrm{O}\right), 59.81$ (C5), $61.10\left(\mathrm{CH}_{3} \mathrm{CH}_{2} \mathrm{O}\right), 103.33$ (C6), 113.72 (C2), $126.70(\mathrm{Ph}-\mathrm{CH}), 127.00$ (Ph-C quat. $\left._{\text {. }}\right)$ 128.35, 129.15, 129.40, 129.62, 129.91, 130.90, 130.95 (Ph-CH), 131.75, 138.92 (Ph-C quat. $_{\text {. }}$, 139.80 (C3), 144.12 (C7), 160.93 (C9), 164.70 (O-C=O); ESI-MS/MS (439) m/z 393, 315, 263, 219; HRMS (ESI-TOF) Calcd for $\mathrm{C}_{27} \mathrm{H}_{23} \mathrm{~N}_{2} \mathrm{O}_{2} \mathrm{~S}^{+}, 439.1480[\mathrm{M}]^{+}$, Found 439.1480 ( $\Delta=0.0 \mathrm{ppm}$ ).

3.2.5. 6-(Ethoxycarbonyl)-3-(4-methoxyphenyl)-5,7-diphenyl-5H-thiazolo[3,2-a]pyrimidin-8-ium bromide $(7 \mathbf{b})$

Yield 83\%; $R_{\mathrm{f}} 0.55$ (tlc, silica, 2:1 hexane:ethyl acetate); mp 236-238 ${ }^{\circ} \mathrm{C} ;{ }^{1} \mathrm{H}-\mathrm{NMR}\left(400 \mathrm{MHz}, \mathrm{CDCl}_{3}\right)$ $\delta 0.78\left(\mathrm{t}, 3 \mathrm{H}, J\right.$ 7.1, $\left.\mathrm{CH}_{3} \mathrm{CH}_{2} \mathrm{O}\right), 3.85\left(\mathrm{q}, 2 \mathrm{H}, J 7.1, \mathrm{CH}_{3} \mathrm{CH}_{2} \mathrm{O}\right), 3.87\left(\mathrm{~s}, 3 \mathrm{H}, \mathrm{OCH}_{3}\right), 6.41(\mathrm{~s}, 1 \mathrm{H}, \mathrm{C} 5-\mathrm{H}), 6.85$ (d, 2H, J 7.5, Ph-CH), 6.92 (d, 2H, J 8.5, 4-OCH $\left.{ }_{3} \mathrm{Ph}-\mathrm{C} 3,5\right), 7.10$ (d, 2H, J 8.5, 4-OCH $\left.{ }_{3} \mathrm{Ph}-\mathrm{C} 2,6\right), 7.15$ (s, 1H, C2-H), 7.17-7.44 (m, 6H, Ph-CH), 7.53 (d, 2H, J 7.7, Ph-CH), $13.34\left(\mathrm{br}, 1 \mathrm{H}, \mathrm{N}^{+} 8-\mathrm{H}\right) ;{ }^{13} \mathrm{C}-\mathrm{NMR}(400$ $\left.\mathrm{MHz}, \mathrm{CDCl}_{3}\right) \delta 13.44\left(\mathrm{CH}_{3} \mathrm{CH}_{2} \mathrm{O}\right), 55.63\left(\mathrm{OCH}_{3}\right), 59.63(\mathrm{C} 5), 61.10\left(\mathrm{CH}_{3} \mathrm{CH}_{2} \mathrm{O}\right), 103.10(\mathrm{C} 6), 113.00$ (C2), 114.55 (Ph-CH), 118.91 (4-OCH $\left.{ }_{3} \mathrm{Ph}-\mathrm{C} 1\right), 126.64,128.35,129.17,129.38,129.60,130.91,131.38$ (Ph-CH), 131.71, 139.00 (Ph-C quat.), 139.84 (C3), 144.24 (C7), 160.70 (C9), $161.56\left(\mathrm{C}-\mathrm{OCH}_{3}\right), 164.74$ (O-C=O); ESI-MS $m / z 469$ [M] ${ }^{+}$, ESI-MS/MS (469) $m / z$ 423, 345, 263, 219, 191; HRMS (ESI-TOF) Calcd for $\mathrm{C}_{28} \mathrm{H}_{25} \mathrm{~N}_{2} \mathrm{O}_{3} \mathrm{~S}^{+}, 469.1586[\mathrm{M}]^{+}$, Found 469.1598 ( $\Delta=2.6 \mathrm{ppm}$ ).

3.2.6. 6-(Ethoxycarbonyl)-3-(4-fluorophenyl)-5,7-diphenyl-5H-thiazolo[3,2-a]pyrimidin-8-ium bromide (7c)

Yield 74\%; $R_{\mathrm{f}} 0.52$ (tlc, silica, 2:1 hexane:ethyl acetate); $\mathrm{mp} 208-210{ }^{\circ} \mathrm{C} ;{ }^{1} \mathrm{H}-\mathrm{NMR}\left(400 \mathrm{MHz}, \mathrm{CDCl}_{3}\right.$ ) $\delta 0.78\left(\mathrm{t}, 3 \mathrm{H}, J\right.$ 7.1, $\left.\mathrm{CH}_{3} \mathrm{CH}_{2} \mathrm{O}\right), 3.85\left(\mathrm{~m}, 2 \mathrm{H}, \mathrm{CH}_{3} \mathrm{CH}_{2} \mathrm{O}\right), 3.87\left(\mathrm{~s}, 3 \mathrm{H}, \mathrm{OCH}_{3}\right), 6.36(\mathrm{~s}, 1 \mathrm{H}, \mathrm{C} 5-\mathrm{H}), 6.83(\mathrm{~d}$, 2H, J 7.5, Ph-CH), 7.10-7.27 (m, 7H, Ph-CH), 7.30 (s, 1H, C2-H), 7.37-7.43 (m, 3H, Ph-CH), 7.52 (d, 2H, J 7.1, Ph-CH), 13.30 (br, $\left.1 \mathrm{H}, \mathrm{N}^{+} 8-\mathrm{H}\right) ;{ }^{13} \mathrm{C}-\mathrm{NMR}\left(400 \mathrm{MHz}, \mathrm{CDCl}_{3}\right) \delta 13.43\left(\mathrm{CH}_{3} \mathrm{CH}_{2} \mathrm{O}\right), 59.93$ (C5), 61.13 $\left(\mathrm{CH}_{3} \mathrm{CH}_{2} \mathrm{O}\right), 103.36$ (C6), 114.60 (C2), 116.30, 116.50 (4-FPh-CH), 123.10 (4-FPh-C1), 126.66, 128.34, 129.23, 129.32, 129.70, 130.91, 130.85 (Ph-CH), 131.75 (Ph- $\mathrm{C}_{\text {quat. }}$ ), 132.13, 132.22 (4-FPh-CH), 138.51 (C3), 138.95 (Ph-C quat. $_{\text {) }} 143.83$ (C7), 160.82 (C9), 164.60 (O-C=O), 162.86, 165.40 (4-FPh-C4); ESI-MS m/z 457 [M] ${ }^{+}$, ESI-MS/MS (457) $\mathrm{m} / \mathrm{z} 411,333,263,219,191$; HRMS (ESI-TOF) Calcd for $\mathrm{C}_{27} \mathrm{H}_{22} \mathrm{FN}_{2} \mathrm{O}_{2} \mathrm{~S}^{+}$, $457.1386[\mathrm{M}]^{+}$, Found $457.1396(\Delta=2.2 \mathrm{ppm})$.

3.2.7. 6-(Ethoxycarbonyl)-5-(4-methoxyphenyl)-3,7-diphenyl-5H-thiazolo[3,2-a]pyrimidin-8-ium bromide $(7 \mathrm{~d})$

Yield 70\%; $R_{\mathrm{f}} 0.40$ (tlc, silica, 2:1 hexane:ethyl acetate); mp 193-195 ${ }^{\circ} \mathrm{C} ;{ }^{1} \mathrm{H}-\mathrm{NMR}(400 \mathrm{MHz}$, $\left.\mathrm{CDCl}_{3}\right) \delta 0.78\left(\mathrm{t}, 3 \mathrm{H}, J\right.$ 7.1, $\left.\mathrm{CH}_{3} \mathrm{CH}_{2} \mathrm{O}\right), 3.74\left(\mathrm{~s}, 3 \mathrm{H}, \mathrm{OCH}_{3}\right), 3.85\left(\mathrm{q}, 2 \mathrm{H}, J\right.$ 7.1, $\left.\mathrm{CH}_{3} \mathrm{CH}_{2} \mathrm{O}\right), 6.73(\mathrm{~s}, 1 \mathrm{H}$, C5-H), $6.65(\mathrm{~d}, 2 \mathrm{H}, J$ 8.6, Ph-CH), $6.71(\mathrm{~d}, 2 \mathrm{H}, J$ 8.6, 4-OCH 3 Ph-C3,5), $7.17(\mathrm{~d}, 3 \mathrm{H}, \mathrm{Ph}-\mathrm{CH}$ and $\mathrm{C} 2-\mathrm{H})$, 
7.41-7.47 (m, 5H, Ph-CH), 7.54 (d, 2H, J 7.0, Ph-CH), 13.37 (br, 1H, N $\left.{ }^{+} 8-\mathrm{H}\right) ;{ }^{13} \mathrm{C}-\mathrm{NMR}(400 \mathrm{MHz}$, $\left.\mathrm{CDCl}_{3}\right) \delta 13.43\left(\mathrm{CH}_{3} \mathrm{CH}_{2} \mathrm{O}\right), 55.42\left(\mathrm{OCH}_{3}\right), 59.41(\mathrm{C} 5), 61.06\left(\mathrm{CH}_{3} \mathrm{CH}_{2} \mathrm{O}\right), 103.45(\mathrm{C} 6), 113.26(\mathrm{C} 2)$, 114.41 (Ph-CH), 127.15 (Ph-C quat.), 128.24, 128.37, 129.18, 129.36, 129.91, 130.87, 130.96 (Ph-CH), 131.71, 131.77 (Ph-C quat. $), 139.88$ (C3), 143.80 (C7), $160.50\left(\right.$ C-OCH $\left._{3}\right), 160.65$ (C9), 164.74 (O-C=O); ESI-MS m/z 469 [M] ${ }^{+}$, ESI-MS/MS (469) $\mathrm{m} / \mathrm{z} 423,315,293,263,249$; HRMS (ESI-TOF) Calcd for $\mathrm{C}_{28} \mathrm{H}_{25} \mathrm{~N}_{2} \mathrm{O}_{3} \mathrm{~S}^{+}$, $469.1586[\mathrm{M}]^{+}$, Found $469.1595(\Delta=1.9 \mathrm{ppm})$.

\subsubsection{Ethyl 3-(4-methoxyphenyl)-5,7-diphenyl-5H-thiazolo[3,2-a]pyrimidine-6-carboxylate (9)}

Yield 70\%; $R_{\mathrm{f}} 0.52$ (tlc, silica, 2:1 hexane:ethyl acetate); mp 205-207 ${ }^{\circ} \mathrm{C} ;{ }^{1} \mathrm{H}-\mathrm{NMR}\left(400 \mathrm{MHz}, \mathrm{CDCl}_{3}\right)$ $\delta 0.78\left(\mathrm{t}, 3 \mathrm{H}, J\right.$ 7 7.1, $\left.\mathrm{CH}_{3} \mathrm{CH}_{2} \mathrm{O}\right), 3.82\left(\mathrm{q}, 2 \mathrm{H}, J\right.$ 7.1, $\left.\mathrm{CH}_{3} \mathrm{CH}_{2} \mathrm{O}\right), 3.86\left(\mathrm{~s}, 3 \mathrm{H}, \mathrm{OCH}_{3}\right), 6.18(\mathrm{~s}, 1 \mathrm{H}, \mathrm{C} 2-\mathrm{H}), 6.27$ $(\mathrm{s}, 1 \mathrm{H}, \mathrm{C} 5-\mathrm{H}), 6.91(\mathrm{~d}, 2 \mathrm{H}, J$ 8.4, Ar-CH), $6.96(\mathrm{~d}, 2 \mathrm{H}, J$ 7.0, Ar-CH), $7.08(\mathrm{~d}, 2 \mathrm{H}, J$ 8.4, Ar-CH), 7.174-7.40 $(\mathrm{m}, 8 \mathrm{H}, \mathrm{Ar}-\mathrm{CH}) ;{ }^{13} \mathrm{C}-\mathrm{NMR}\left(400 \mathrm{MHz}, \mathrm{CDCl}_{3}\right) \delta 13.62\left(\mathrm{CH}_{3} \mathrm{CH}_{2} \mathrm{O}\right), 55.53\left(\mathrm{OCH}_{3}\right), 58.36(\mathrm{C} 5), 59.75$ $\left(\mathrm{CH}_{3} \mathrm{CH}_{2} \mathrm{O}\right), 100.57$ (C6), $103.04(\mathrm{C} 2), 114.21$ (Ar-CH), $121.82(\mathrm{C} 3), 126.56,127.70,128.26,128.40,128.50$, 130.60 (Ph-CH), 139.70, 141.04, 142.40 (Ar-C quat. $\left._{\text {. }}\right), 156.26$ (C7), $160.75\left(\mathrm{C}-\mathrm{OCH}_{3}\right), 166.53$ (C9), 167.04 $(\mathrm{O}-\mathrm{C}=\mathrm{O})$.

\subsection{Molecular Docking Studies}

The protein structure was prepared starting from the crystallographic complex of human AChE in complex with the AChE inhibitor Territrem B (PDB ID: 4m0f, chain A). Territrem B and other non-protein molecules were deleted and only the enzyme chain was retained. Hydrogen atoms and missing heavy atoms were added. Zero occupancy side chains, polar hydrogen atoms, and the positions of asparagine and glutamine side chain amidic groups were optimized and assigned the lowest energy conformation. The Autodock Vina software [39] was used for the molecular docking process using a flexible protein-flexible ligand approach. The protein flexible regions were defined as spherical regions with a radius of $11 \AA$ centered at the geometrical center of the Territrem B binding site. The docking search space was defined as a cubic $30 \times 45 \times 30 \AA^{3}$ box co-centrical with the flexible region. Docking was performed with an exhaustiveness of 32 and the top 100 binding modes within $10 \mathrm{kcal} / \mathrm{mol}$ of the top binding mode were recorded and analyzed. Protein-ligand analyses were performed with UCSF Chimera [55].

\subsection{Enzyme Inhibition Activity}

\subsubsection{Enzyme and Assay Reagents}

Recombinant Human Acetylcholinesterase (rhAChE, catalog number 7574-CE, expressed in Chinese hamster ovary cells) was purchased from R\&D Systems. 5,5'-Dithiobis(2-nitrobenzoic acid) (DTNB, Ellman's reagent), acetylthiocholine iodide (ACTI), and the methyl paraoxon used as reference AChE inhibitor were purchased from Sigma-Aldrich (Schnelldorf, Germany).

\subsubsection{In Vitro Acetylcholinesterase Activity Assay}

The inhibitory activities of the synthesized compounds on $h \mathrm{AChE}$ were evaluated using a colorimetric Ellman-based method, with methyl paraoxon as the reference compound [43]. The inhibitors were dissolved in DMSO, acetylthiocholine iodide (ACTI, $20 \mathrm{mM}$ ) was dissolved in distilled water, and the dithiobis(2-nitrobenzoic acid) (DTNB, $10 \mathrm{mM}$ ) and methyl paraoxon $(20 \mathrm{mM})$ were dissolved in assay buffer. Prior to use, all refrigerated solutions were allowed to reach room temperature. Enzyme $(100 \mu \mathrm{L}, 0.2 \mu \mathrm{g} / \mathrm{mL})$ and inhibitor solutions $(20 \mu \mathrm{L})$ were added into a cuvette containing $4.0 \mathrm{~mL}$ assay buffer ( $100 \mathrm{mM}$ sodium phosphate, $\mathrm{pH} 7.4 / 1 \mathrm{mM}$ EDTA). After 10 min incubation at room temperature, required aliquots of the DTNB $(20 \mu \mathrm{L})$ and the ACTI $(20 \mu \mathrm{L})$ solutions were added. After gently mixing, the total mixture was incubated at $37^{\circ} \mathrm{C}$ for $35 \mathrm{~min}$. The absorption was measured at $405 \mathrm{~nm}$ on a Shimadzu 3101PC UV-vis spectrophotometer and corrected for background. The specific inhibition extents were calculated in reference to measurements performed under the same 
conditions in the absence of inhibitor and expressed as percentage inhibition. For comparative purposes, the standard inhibitor, methyl paraoxon, was tested concomitantly, giving $>95-100 \%$ inhibition in all instances. The enzyme activity was determined in the presence of concentrations up to $50 \mu \mathrm{M}$ for any given inhibitor. The same concentrations were used for methyl paraoxon. The measurements were conducted immediately after sample preparation. Inhibition curves were produced to calculate the $\mathrm{IC}_{50}$ values.

\section{Conclusions}

In summary, we synthesized a series of fused thiazolo[3,2-a]pyrimidines in good yields from 3,4-dihydropyrimidinethione precursors. All compounds were fully characterized by 1D- and 2D-NMR, high resolution ESI-MS/MS, and single crystal X-ray diffraction analysis, which confirmed a regioselective $5 \mathrm{H}$ cyclization of the DHPMs. All target compounds were screened in vitro as $h \mathrm{AChE}$ inhibitors via an Ellman-based colorimetric assay and showed good inhibition activities (better than $70 \%$ ) at $10 \mu \mathrm{M}$, with $\mathrm{IC}_{50} \mathrm{~s}$ in the $1 \mu \mathrm{M}$ range. Molecular docking simulations for all target products into $h \mathrm{AChE}$ were performed and confirmed strong binding to the peripheral anionic site of the enzyme, at the mouth of the catalytic gorge, which funnels access to the catalytic site. These preliminary data set the ground for further improvement of the core structure and provide a new and promising starting point to develop new acetylcholinesterase inhibitors and explore novel treatment options against Alzheimer's disease.

Supplementary Materials: The supplementary materials are available online.

Author Contributions: A.M.E., A.-E.A.H and M.M.M. designed the study. M.Y.M. was responsible for the synthesis, NMR characterization, Hirshfeld surface analysis, and in vitro $h$ AChE inhibition studies. He wrote the preliminary draft of the manuscript. J.L.F.d.S was responsible for the X-ray characterization studies and wrote the corresponding sections. G.C.J. performed the docking studies and wrote the corresponding section. A.M.E. and M.M.M. critically reviewed and edited the whole manuscript, with input from all the authors.

Funding: This work was supported in part by Fundação para a Ciência e a Tecnologia (FCT, Portugal), through grants UID/QUI/00100/2013, UID/QUI/100/2019, SAICTPAC/0019/2015, and PTDC/QUI-QAN/32242/2017, funded by national funds through FCT/MEC and when appropriate co-financed by FEDER under the PT2020 Partnership Agreement. MYM also thanks the Egyptian Higher Education Ministry, Cultural Affairs, and Missions sector for financial support. Thanks are also due to the Portuguese Mass Spectrometry Network (Grant LISBOA-01-0145-FEDER-022125).

Conflicts of Interest: The authors declare no conflicts of interest. The funders had no role in the design of the study; in the collection, analyses, or interpretation of data; in the writing of the manuscript, and in the decision to publish the results.

\section{References}

1. World Alzheimer Report 2018. Available online: https://www.alz.co.uk/research/world-report (accessed on 10 March 2019).

2. Francis, P.T.; Palmer, A.M.; Snape, M.; Wilcock, G.K. The cholinergic hypothesis of Alzheimer's disease: A review of progress. J. Neurol. Neurosurg. Psychiatry 1999, 66, 137-147. [CrossRef] [PubMed]

3. Castro, A.; Martinez, A. Peripheral and dual binding site acetylcholinesterase inhibitors: Implications in treatment of Alzheimer's disease. Mini Rev. Med. Chem. 2001, 1, 267-272. [CrossRef] [PubMed]

4. Arias, E.; Gallego-Sandín, S.; Villarroya, M.; García, A.G.; López, M.G. Unequal neuroprotection afforded by the acetylcholinesterase inhibitors galantamine, donepezil, and rivastigmine in $\mathrm{SH}_{-} \mathrm{SY}_{5} \mathrm{Y}$ neuroblastoma cells: role of nicotinic receptors. J. Pharmacol. Exp. Ther. 2005, 315, 1346-1353. [CrossRef] [PubMed]

5. Zhi, H.; Chen, L.; Zhang, L.; Liu, S.; Cheong, C. Design, synthesis, and biological evaluation of $5 \mathrm{H}$-thiazolo[3,2-a]pyrimidine derivatives as a new type of acetylcholinesterase inhibitors. Arkivoc 2008, 2008, 266-277.

6. Kolb, S.; Mondésert, O.; Goddard, M.L.; Jullien, D.; Villoutreix, B.O.; Ducommun, B.; Garbay, C.; Braud, E. Development of novel thiazolopyrimidines as CDC25B phosphatase inhibitors. ChemMedChem 2009, 4, 633-648. [CrossRef] [PubMed] 
7. Jin, C.H.; Jun, K.Y.; Lee, E.; Kim, S.; Kwon, Y.; Kim, K.; Na, Y. Ethyl 2-(benzylidene)-7-methyl-3-oxo-2,3dihydro-5H-thiazolo[3,2-a] pyrimidine-6-carboxylate analogues as a new scaffold for protein kinase casein kinase 2 inhibitor. Bioorganic Med. Chem. 2014, 22, 4553-4565. [CrossRef] [PubMed]

8. Zhao, D.; Chen, C.; Liu, H.; Zheng, L.; Tong, Y.; Qu, D.; Han, S. Biological evaluation of halogenated thiazolo[3,2-a]pyrimidin-3-one carboxylic acid derivatives targeting the YycG histidine kinase. Eur. J. Med. Chem. 2014, 87, 500-507. [CrossRef]

9. Geist, J.G.; Lauw, S.; Illarionova, V.; Illarionov, B.; Fischer, M.; Gräwert, T.; Rohdich, F.; Eisenreich, W.; Kaiser, J.; Groll, M.; et al. Thiazolopyrimidine inhibitors of 2-methylerythritol 2,4-cyclodiphosphate synthase (IspF) from Mycobacterium tuberculosis and Plasmodium falciparum. ChemMedChem 2010, 5, 1092-1101. [CrossRef] [PubMed]

10. Khobragade, C.N.; Bodade, R.G.; Dawane, B.S.; Konda, S.G.; Khandare, N.T. Synthesis and biological activity of pyrazolo[3,4-d]thiazolo[3,2-a]pyrimidin-4-one derivatives: in silico approach. J. Enzyme Inhib. Med. Chem. 2010, 25, 615-621. [CrossRef] [PubMed]

11. Hassan, G.S.; El-Messery, S.M.; Abbas, A. Synthesis and anticancer activity of new thiazolo[3,2-a]pyrimidines: DNA binding and molecular modeling study. Bioorg. Chem. 2017, 74, 41-52. [CrossRef]

12. Abdel Moty, S.G.; Hussein, M.A.; Abdel Aziz, S.A.; Abou-Salim, M.A. Design and synthesis of some substituted thiazolo[3,2-a]pyrimidine derivatives of potential biological activities. Saudi Pharm. J. 2016, 24, 119-132. [CrossRef] [PubMed]

13. Chen, L.; Jin, Y.; Fu, W.; Xiao, S.; Feng, C.; Fang, B.; Gu, Y.; Li, C.; Zhao, Y.; Liu, Z.; et al. Design, synthesis, and structure-activity relationship analysis of thiazolo[3,2-a]pyrimidine derivatives with anti-inflammatory activity in acute lung injury. ChemMedChem 2017, 12, 1022-1032. [CrossRef] [PubMed]

14. Tozkoparan, B.; Yarim, M.; Saraç, S.; Ertan, M.; Kelicen, P.; Altinok, G.; Demirdamar, R. Studies on synthesis, chromatographic resolution, and antiinflammatory activities of some 2-thioxo-1,2,3,4-tetrahydropyrimidines and their condensed derivatives. Arch. Pharm. (Weinheim) 2000, 333, 415-420. [CrossRef]

15. Sawant, R.L.; Bansode, C.A.; Wadekar, J.B. In vitro anti-inflammatory potential and QSAR analysis of oxazolo/thiazolo pyrimidine derivatives. Med. Chem. Res. 2013, 22, 1884-1892. [CrossRef]

16. Pan, B.; Huang, R.; Zheng, L.; Chen, C.; Han, S.; Qu, D.; Zhu, M.; Wei, P. Thiazolidione derivatives as novel antibiofilm agents: Design, synthesis, biological evaluation, and structure-activity relationships. Eur. J. Med. Chem. 2011, 46, 819-824. [CrossRef] [PubMed]

17. Banothu, J.; Khanapur, M.; Basavoju, S.; Bavantula, R.; Narra, M.; Abbagani, S. Synthesis, characterization and biological evaluation of fused thiazolo[3,2-a]pyrimidine derivatives. RSC Adv. 2014, 4, 22866. [CrossRef]

18. Gali, R.; Banothu, J.; Porika, M.; Velpula, R.; Hnamte, S.; Bavantula, R.; Abbagani, S.; Busi, S. Indolylmethylene benzo[ $h]$ thiazolo[2- $b$ ]quinazolinones: Synthesis, characterization and evaluation of anticancer and antimicrobial activities. Bioorg. Med. Chem. Lett. 2014, 24, 4239-4242. [CrossRef]

19. Abu-Hashem, A.A.; Youssef, M.M.; Hussein, H.A.R. Synthesis, antioxidant, antituomer activities of some new thiazolopyrimidines, pyrrolothiazolopyrimidines and triazolopyrrolothiazolopyrimidines derivatives. J. Chinese Chem. Soc. 2011, 58, 41-48. [CrossRef]

20. Ergan, E.; Akbas, E.; Levent, A.; Sahin, E.; Konus, M.; Seferoglu, N. Synthesis, theoretical calculation, electrochemistry and total antioxidant capacity of 5-benzoyl-6-phenyl-4-(4-methoxyphenyl)1,2,3,4-tetrahydro-2-thioxopyrimidine and derivatives. J. Mol. Struct. 2017, 1136, 231-243. [CrossRef]

21. Mohamed, S.F.; Flefel, E.M.; Amr, A.E.G.E.; Abd El-Shafy, D.N. Anti-HSV-1 activity and mechanism of action of some new synthesized substituted pyrimidine, thiopyrimidine and thiazolopyrimidine derivatives. Eur. J. Med. Chem. 2010, 45, 1494-1501. [CrossRef]

22. Ravendra Babu, K.; Koteswara Rao, V.; Nanda Kumar, Y.; Polireddy, K.; Venkata Subbaiah, K.; Bhaskar, M.; Lokanatha, V.; Naga Raju, C. Identification of substituted [3, 2-a] pyrimidines as selective antiviral agents: Molecular modeling study. Antiviral Res. 2012, 95, 118-127. [CrossRef] [PubMed]

23. Amr, A.E.-G.E.; Maigali, S.S.; Abdulla, M.M. Synthesis, and analgesic and antiparkinsonian activities of thiopyrimidine, pyrane, pyrazoline, and thiazolopyrimidine derivatives from 2-chloro-6-ethoxy-4-acetylpyridine. Monatshefte für Chemie-Chem. Mon. 2008, 139, 1409-1415. [CrossRef]

24. Batool, I.; Saeed, A.; Qureshi, I.Z.; Kalsoom, S.; Razzaq, A. Synthesis, molecular docking and biological evaluation of new thiazolopyrimidine carboxylates as potential antidiabetic and antibacterial agents. Res. Chem. Intermed. 2016, 42, 1139-1163. [CrossRef] 
25. Jeanneau-Nicolle, E.; Benoit-Guyod, M.; Namil, A.; Leclerc, G. New thiazolo[3,2-a]pyrimidine derivatives, synthesis and structure-activity relationships. Eur. J. Med. Chem. 1992, 27, 115-120. [CrossRef]

26. Fatima, S.; Sharma, A.; Saxena, R.; Tripathi, R.; Shukla, S.K.; Pandey, S.K.; Tripathi, R.; Tripathi, R.P. One pot efficient diversity oriented synthesis of polyfunctional styryl thiazolopyrimidines and their bio-evaluation as antimalarial and anti-HIV agents. Eur. J. Med. Chem. 2012, 55, 195-204. [CrossRef] [PubMed]

27. Ruiu, S.; Marchese, G.; Saba, P.L.; Gessa, G.L.; Pani, L. The 5-HT 2 antagonist ritanserin blocks dopamine re-uptake in the rat frontal cortex. Mol. Psychiatry 2000, 5, 673-677. [CrossRef] [PubMed]

28. Meyer, J.H.; Kapur, S.; Houle, S.; DaSilva, J.; Owczarek, B.; Brown, G.M.; Wilson, A.A.; Kennedy, S.H. Prefrontal Cortex 5-HT $\mathrm{HT}_{2}$ Receptors in Depression: An [ $\left.{ }^{18} \mathrm{~F}\right]$ Setoperone PET Imaging Study. Am. J. Psychiatry 1999, 156, 1029-1034. [CrossRef]

29. Serrar, H.; Galai, M.; Benhiba, F.; Ouakki, M.; Benzekri, Z.; Boukhris, S.; Hassikou, A.; Souizi, A.; Oudda, H.; Ebn Touhami, M. Two derivatives of 7-amino-thiazolo[3,2-a]pyrimidine as inhibitors of mild steel corrosion in $1.0 \mathrm{M} \mathrm{HCl}$ solution: Part I: Synthesis of inhibitors and electrochemical study. J. Chem. Technol. Metall. 2018, 53, 324-335.

30. Lashmanova, E.A.; Kirdyashkina, A.I.; Slepukhin, P.A.; Shiryaev, A.K. Oxidation of thiazolo[3,2-a]pyrimidin3(2H)-ones with DMSO and Lawesson's reagent. Tetrahedron Lett. 2018, 59, 1099-1103. [CrossRef]

31. Elmaghraby, A.M.; Mousa, I.A.; Harb, A.A.; Mahgoub, M.Y. Three Component Reaction: An Efficient Synthesis and Reactions of 3,4-Dihydropyrimidin-2(1H)-Ones and Thiones Using New Natural Catalyst. ISRN Org Chem. 2013. [CrossRef]

32. Allen, F.H.; Kennard, O.; Watson, D.G.; Brammer, L.; Orpen, A.G.; Taylor, R. Tables of bond lengths determined by X-ray and neutron diffraction. Part 1. Bond lengths in organic compounds. J. Chem. Soc. Perkin Trans. 1987, 2, S1-S19. [CrossRef]

33. Orpen, A.G.; Brammer, L.; Allen, F.H.; Kennard, O.; Watson, D.G.; Taylor, R. Supplement. Tables of bond lengths determined by $\mathrm{X}$-ray and neutron diffraction. Part 2. Organometallic compounds and co-ordination complexes of the d- and f-block metals. J. Chem. Soc. Dalt. Trans. 1989, S1-S83. [CrossRef]

34. Kitaigorodskii, A.I. Organic Chemical Crystallography; Consultants Bureau: New York, NY, USA, 1961.

35. Wolff, D.J.; Grimwood, J.J.; McKinnon, M.J.; Turner, D.; Jayatilaka, M.A.S. Crystal Explorer 3.1; University of Western Australia: Perth, Australia, 2012.

36. McKinnon, J.J.; Jayatilaka, D.; Spackman, M.A. Towards quantitative analysis of intermolecular interactions with Hirshfeld surfaces. Chem. Commun. 2007, 3814-3816. [CrossRef]

37. McKinnon, J.J.; Spackman, M.A.; Mitchell, A.S. Novel tools for visualizing and exploring intermolecular interactions in molecular crystals. Acta Crystallogr. Sect. B Struct. Sci. 2004, 60, 627-668. [CrossRef]

38. Spackman, M.A.; Jayatilaka, D. Hirshfeld surface analysis. CrystEngComm 2009, 11, 19-32. [CrossRef]

39. Trott, O.; Olson, A.J. AutoDock Vina: Improving the speed and accuracy of docking with a new scoring function, efficient optimization, and multithreading. J. Comput. Chem. 2009, 31, 455-461. [CrossRef]

40. Bourne, Y.; Taylor, P.; Radić, Z.; Marchot, P. Structural insights into ligand interactions at the acetylcholinesterase peripheral anionic site. EMBO J. 2003, 22, 1-12. [CrossRef]

41. Colletier, J.; Fournier, D.; Greenblatt, H.M.; Stojan, J.; Sussman, J.L.; Zaccai, G.; Silman, I.; Weik, M. Structural insights into substrate traffic and inhibition in acetylcholinesterase. EMBO J. 2006, 25, 2746-2756. [CrossRef]

42. Cheung, J.; Gary, E.N.; Shiomi, K.; Rosenberry, T.L. Structures of human acetylcholinesterase bound to dihydrotanshinone I and territrem B show peripheral site flexibility. ACS Med. Chem. Lett. 2013, 4, 1091-1096. [CrossRef]

43. Ellman, G.L.; Courtney, K.D.; Andres, V.; Featherstone, R.M. A new and rapid colorimetric determination of acetylcholinesterase activity. Biochem. Pharmacol. 1961, 7, 88-95. [CrossRef]

44. Ogura, H.; Kosasa, T.; Kuriya, Y.; Yamanishi, Y. Comparison of inhibitory activities of donepezil and other cholinesterase inhibitors on acetylcholinesterase and butyrylcholinesterase in vitro. Methods Find. Exp. Clin. Pharmacol. 2000, 22, 609-613. [CrossRef]

45. Armarego WLF, C.C. Purification of Laboratory Chemicals, 7th ed.; Elsevier Inc.: Oxford, UK, 2013.

46. SMART and SAINT. Control and Integration Software; Bruker AXS: Madison, WI, USA, 2004.

47. Krause, L.; Herbst-Irmer, R.; Sheldrick, G.M.; Stalke, D. Comparison of silver and molybdenum microfocus X-ray sources for single-crystal structure determination. J. Appl. Crystallogr. 2015, 48, 3-10. [CrossRef]

48. Sheldrick, G.M. IUCr SHELXT-Integrated space-group and crystal-structure determination. Acta Crystallogr. Sect. A Found. Adv. 2015, 71, 3-8. [CrossRef] 
49. Sheldrick, G.M. Crystal structure refinement with SHELXL. Acta Cryst. 2014, C71, 3-8. [CrossRef]

50. Farrugia, L.J. WinGX and ORTEP for Windows: An update. J. Appl. Crystallogr. 2012, 45, 849-854. [CrossRef]

51. Macrae, C.F.; Bruno, I.J.; Chisholm, J.A.; Edgington, P.R.; McCabe, P.; Pidcock, E.; Rodriguez-Monge, L.; Taylor, R.; Van De Streek, J.; Wood, P.A. Mercury CSD 2.0-New features for the visualization and investigation of crystal structures. J. Appl. Crystallogr. 2008, 41, 466-470. [CrossRef]

52. Dolomanov, O.V.; Bourhis, L.J.; Gildea, R.J.; Howard, J.A.K.; Puschmann, H. OLEX2: A complete structure solution, refinement and analysis program. J. Appl. Crystallogr. 2009, 42, 339-341. [CrossRef]

53. Spek, A.L. Structure validation in chemical crystallography. Acta Crystallogr. Sect. D Biol. Crystallogr. 2009, 65, 148-155. [CrossRef]

54. Sherif, S.M.; Youssef, M.M.; Mobarak, K.M. A Convenient Synthesis of Thiazolopyrimidines, Thiazolodipyrimidines and Heterocyclo thiazolopyrimidines. Tetrahedron 1993, 49, 9561-9572. [CrossRef]

55. Pettersen, E.F.; Goddard, T.M.; Huang, C.C.; Couch, G.S.; Greenblatt, D.M.; Meng, E.C.; Ferrin, T.E. UCSF Chimera-A visualization system for exploratory research and analysis. J. Comput. Chem. 2004, 25, 1605-1612. [CrossRef]

Sample Availability: Samples of the compounds $4 \mathbf{a}-\mathbf{b}$ and $7 \mathbf{a}-\mathbf{d}$ are available from the authors.

(C) 2019 by the authors. Licensee MDPI, Basel, Switzerland. This article is an open access article distributed under the terms and conditions of the Creative Commons Attribution (CC BY) license (http://creativecommons.org/licenses/by/4.0/). 